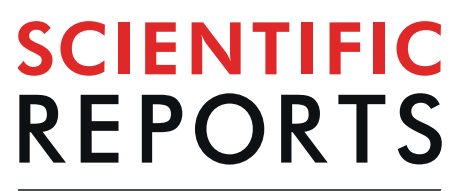

natureresearch

\title{
Cyanide produced with ethylene by ACS and its incomplete detoxification by $\beta$-CAS in mango inflorescence leads to malformation
}

\author{
Mohammad Wahid Ansari ${ }^{1,2,4,6}$, Shail Kaushik ${ }^{2,6}$, Gurdeep Bains ${ }^{2,6}$, Suresh Tula ${ }^{1,3}$, \\ Bhavana Joshi ${ }^{2}$, Varsha Rani ${ }^{2}$, Ratnum Kaul Wattal ${ }^{4}$, Randeep Rakwal $\mathbb{D}^{5}$, Alok Shukla ${ }^{2}$, \\ Ramesh Chandra Pant ${ }^{2}$, Renu Tuteja ${ }^{1}$ \& Narendra Tuteja ${ }^{1^{*}}$
}

Malformation of mango inflorescences (MMI) disease causes severe economic losses worldwide. Present research investigates the underlying causes of MMI. Results revealed significantly higher levels of cyanide, a by-product of ethylene biosynthesis, in malformed inflorescences (MI) of mango cultivars. There was a significant rise in ACS transcripts, ACS enzyme activity and cyanide and ethylene levels in $\mathrm{MI}$ as compared to healthy inflorescences $(\mathrm{HI})$. Significant differences in levels of methionine, phosphate, S-adenosyl-L-methionine, S-adenosyl-L-homocysteine, ascorbate and glutathione, and activities of dehydroascorbate reductase and glutathione reductase were seen in MI over HI. Further, a lower expression of $\beta$-cyanoalanine synthase ( $\beta$-CAS) transcript was associated with decreased cellular $\beta$-CAS activity in MI, indicating accumulation of unmetabolized cyanide. TEM studies showed increased gum-resinosis and necrotic cell organelles, which might be attributed to unmetabolized cyanide. In field trials, increased malformed-necrotic-inflorescence (MNI) by spraying ethrel and decreased MNI by treating with ethylene inhibitors (silver and cobalt ions) further confirmed the involvement of cyanide in MMI. Implying a role for cyanide in MMI at the physiological and molecular level, this study will contribute to better understanding of the etiology of mango inflorescence malformation, and also help manipulate mango varieties genetically for resistance to malformation.

Mango inflorescence is a branched raceme with pedicellate flowers arranged acropetally, which bears 500 yellowish-green bisexual and male flowers in variable proportion ${ }^{1,2}$. However, malformed inflorescences do not set fruit; therefore, inflorescence malformation in mango trees is a terrible disease ${ }^{3}$ for mango farmers in that it reduces fruit productivity by $50-80$ percent each year ${ }^{4}$. The disease was first identified in India by Marries, an expert mango grower from the Darbhanga district of Bihar ${ }^{5,6}$. Since then, it has been recognized in other mango producing countries such as Pakistan, the Middle East, Egypt, South Africa, Brazil, Sudan, Central America, Mexico, Cuba, Malaysia, Australia, Israel, UAE, Bangladesh, Sultanate of Oman, Southern Spain, China, United States and Senegal ${ }^{6}$. Mango malformation is a complex and destructive disease, which is exacerbated by the inadequate knowledge of its etiology.

Previously, we have reported higher content of ethylene in $\mathrm{MMI}^{7,8}$. In addition to producing ethylene, Fusarium mangiferae leads to the overexpression of key mango genes ${ }^{10,11}$, which affects plant hormone homeostasis $^{12}$ and results in stress hormone ethylene formation ${ }^{7}$. Cyanide, a co-product of ethylene synthesis exerts adverse, toxic and long-term effects on plant growth and development ${ }^{13,14}$. Therefore, cyanide derived from ethylene could contribute to the development of malformation. In non-cyanogenic plants, cyanide is usually not detoxified by the $\beta$-CAS enzyme under adverse condition ${ }^{13}$. Thus, the accumulated unmetabolized cyanide

${ }^{1}$ International Centre for Genetic Engineering and Biotechnology (ICGEB), Aruna Asaf Ali Marg, 110067, New Delhi, India. ${ }^{2}$ Department of Plant Physiology, CBSH, G. B. Pant University of Agriculture and Technology, Pantnagar, 263145, India. ${ }^{3}$ Institute of Plant Genetics and Crop Plant Research (IPK), Molecular Plant Nutrition, Corrensstr. 3, 06466, Gatersleben, Germany. ${ }^{4}$ Department of Botany, Zakir Husain Delhi College (University of Delhi), Jawahar Lal Nehru Marg, 110002, New Delhi, India. ${ }^{5}$ Faculty of Health and Sport Sciences, University of Tsukuba, 1-1-1 Tennodai, Tsukuba, 305-8574, Ibaraki, Japan. ${ }^{6}$ These authors contributed equally: Mohammad Wahid Ansari, Shail Kaushik and Gurdeep Bains. *email: narendra@icgeb.res.in 
causes abnormal development of flower via restricted cell elongation, reduced elongation of rachis, deformation of reproductive organs, trichome formation, necrosis and cell death ${ }^{13,15,16}$. The expression analysis of key genes of cyanide and ethylene metabolism during the course of malformation is decisive to determine the etiology of disease, and, which has not been studied so far.

Cyanide is produced during the ethylene biosynthesis pathway in which the enzyme ACC synthase (ACS) catalyzes the rate-limiting step ${ }^{17,18}$; further, increased endogenous cyanide is associated with enhanced cellular ACS activity ${ }^{19}$. Sato et al..$^{20}$ cloned the first ACS gene from Cucurbita pepo. ACS gene has also been characterized from many other plant species ${ }^{21,22}$. Nevertheless, ACS genes in the mango malformation system have not yet been investigated. In the methionine cycle, cyanide synthesis along with ethylene takes place without demanding additional methionine ${ }^{23,24}$. This will cause accumulation of inorganic phosphorous (PPi and $\left.\mathrm{Pi}\right)^{25}$. The last step of cyanide synthesis is during the conversion of ACC to ethylene catalyzed by ACC oxidase (ACO), which is oxygen dependent, and utilizes $\mathrm{Fe}^{2+}$ and ascorbate (ASA) ${ }^{26}$. Dehydroascorbate reductase (DHAR) enzyme reduces dehydroascorbate (DHA) to ASA using glutathione (GSH) as an electron donor ${ }^{27}$. DHAR, GSH, and GR maintain the endogenous ASA pool ${ }^{28}$. The cyanide is a degraded product of ACC, which is derived from methionine. The methionine cycle revolving at a higher pace explains the higher content of cyanide affecting respiratory rate and flower growth ${ }^{29}$. Additionally, besides cyanide the level of other byproducts of ethylene biosynthesis such as ascorbate, inorganic phosphate, and methionine and other biomolecules and antioxidants might be crucial for the development of malformation, and which also needs to be examined. Cyanide plays a dual role in plants; it may be toxic at high concentration or may have regulatory role towards stress respons $e^{30}$. $\beta$-cyanoalanine synthase $(\beta-C A S)$ is primarily responsible for cyanide detoxification in plants ${ }^{31}$. Most plants were reported to exhibit higher cyanide levels together with low level of $\beta$-CAS in response to stress ${ }^{29,32}$. $\beta$-CAS enzyme is localized to mitochondria ${ }^{33}$ to protect the electron transport chain of mitochondria at the site of cyanide production ${ }^{34}$. Although $\beta$-CAS genes were studied in several plant species ${ }^{35}$, there are no reports of $\beta$-CAS transcript accumulation and cyanide detoxification in the mango malformation system.

The present study aims to study the comparative expression profiles of ACS and $\beta$-CAS in malformed and healthy inflorescence (abbreviated as, MI and HI, respectively) of three mango cultivars - Mallika (Mk), Ramkela $(\mathrm{Rk})$, and Langra ( $\mathrm{Ln})$ differing in their degree of susceptibility to mango malformation disease. We have used these cultivars to correlate physiological and molecular study with cultivar susceptiblity. We investigated the endogenous cyanide content, ethylene pool, and levels of other biomolecules, which may trigger the malformed necrotic inflorescence. Further, transmission electron microscopy was utilized to study the morphological differences in malformed and healthy sections of the mango cultivar Rk. Finally, the response of exogenously applied inhibitors of cyanide/ethylene in the incidence of mango malformation under field conditions was also examined. Our study attempts to provide insights into the etiology of mango malformation and to help devise strategies to control the malformation of mango inflorescences (MMI) disease.

\section{Results}

Expression analysis of ACS transcript, and measuring the ACS activity, ethylene content and cyanide level. Ethylene biosynthesis is conserved in mango plants ${ }^{7}$. Its main regulatory enzymes are ACC synthase and ACC oxidase which are positively or negatively altered by abiotic stresses ${ }^{17}$. The byproducts of ethylene biosynthesis in plants are methionine, S-adenosyl-L-methionine (SAM), inorganic phosphate, ascorbate and cyanide (Fig. 1A). The amino acid sequence alignment of ACS of diverse plant species shows apparent regions of conservation, quality, and consensus between 4-44 amino acids (Fig. 1B). The MI showed a significant increase in the transcript levels of $A C S$ in all tested cultivars as compared with HI. The transcript levels of ACS in the MI of $\mathrm{Mk}, \mathrm{Rk}$ and Ln cultivars were 5.46, 4.5, and 4.33 fold higher than in the HI (Fig. 1C). The ACS activity (nmol ACC mg protein ${ }^{-1} \mathrm{~h}^{-1}$ ) was the highest in the MI of the susceptible mango cultivar Mk (217) followed by relatively tolerant cultivars such as Rk and Ln (199 and 148) as compared with the HI (Fig. 1D). The endogenous ethylene content (pmol g ${ }^{-1} \mathrm{FW} \mathrm{min}^{-2}$ ) of floral tissues was significantly elevated in MI as compared to HI (Fig. 1E). The cultivar Mk showed the highest (107.19), and Ln showed the lowest endogenous ethylene (87.21) content (Fig. 1E). The endogenous cyanide level (ppb) of floral tissues was significantly increased in MI as compared to HI (Fig. 1F). The cultivar Mk revealed the maximum (4.6), and Ln exhibited the lowest endogenous cyanide (3.1) level (Fig. 1F).

Endogenous methionine content, the cations and anions concentration, and $S$-adenosyl-L-methionine (SAM) and S-adenosyl-L-homocysteine (SAH) content and the SAH/ SAM ratio. The endogenous methionine content of MI was not significantly different from that of $\mathrm{HI}$ in any of the cultivars. Moreover, the varietal differences were also not significant (Fig. 2A). Ion chromatography revealed that MI of all the cultivars had significantly higher concentrations of phosphate as compared with their healthy counterparts of mango cultivars Mk, Rk and Ln (Fig. 2B). However, a consistent pattern was not observed in the difference in the concentration of cations (Supplementary Table S1) and anions (Supplementary Table S2) between $\mathrm{MI}$ and $\mathrm{HI}$ of mango cultivars Mk, Rk, and Ln.

The endogenous levels of SAM were significantly lower in MI as compared with HI (Fig. 2C), whereas SAH levels were higher in MI than HI of all tested cultivars (Fig. 2D). Accordingly, the SAH/SAM ratio of MI (9.13, 6.98 and 6.39) was significantly higher than $\mathrm{HI}(2.02,2.06$ and 2.05$)$ of cultivars Mk, Rk and Ln, respectively (Fig. 2E).

Endogenous ascorbate level, dehydroascorbate reductase and the ratio of ASA/DHA. The final reaction of the pathway that results in the production of ethylene from 1-aminocyclopropane-1-carboxylic acid (ACC) molecule is catalyzed by the enzyme ACC oxidase, which requires $\mathrm{Fe}^{2+}$, ascorbate and $\mathrm{O}_{2}$ (Fig. 3A). The $\mathrm{MI}$ of Mk, Rk and Ln showed significantly lower ascorbate (ASA) $\left(4.16,6.34\right.$ and $\left.7.68 \mu \mathrm{mole}^{-1} \mathrm{FW}\right)$ than HI 


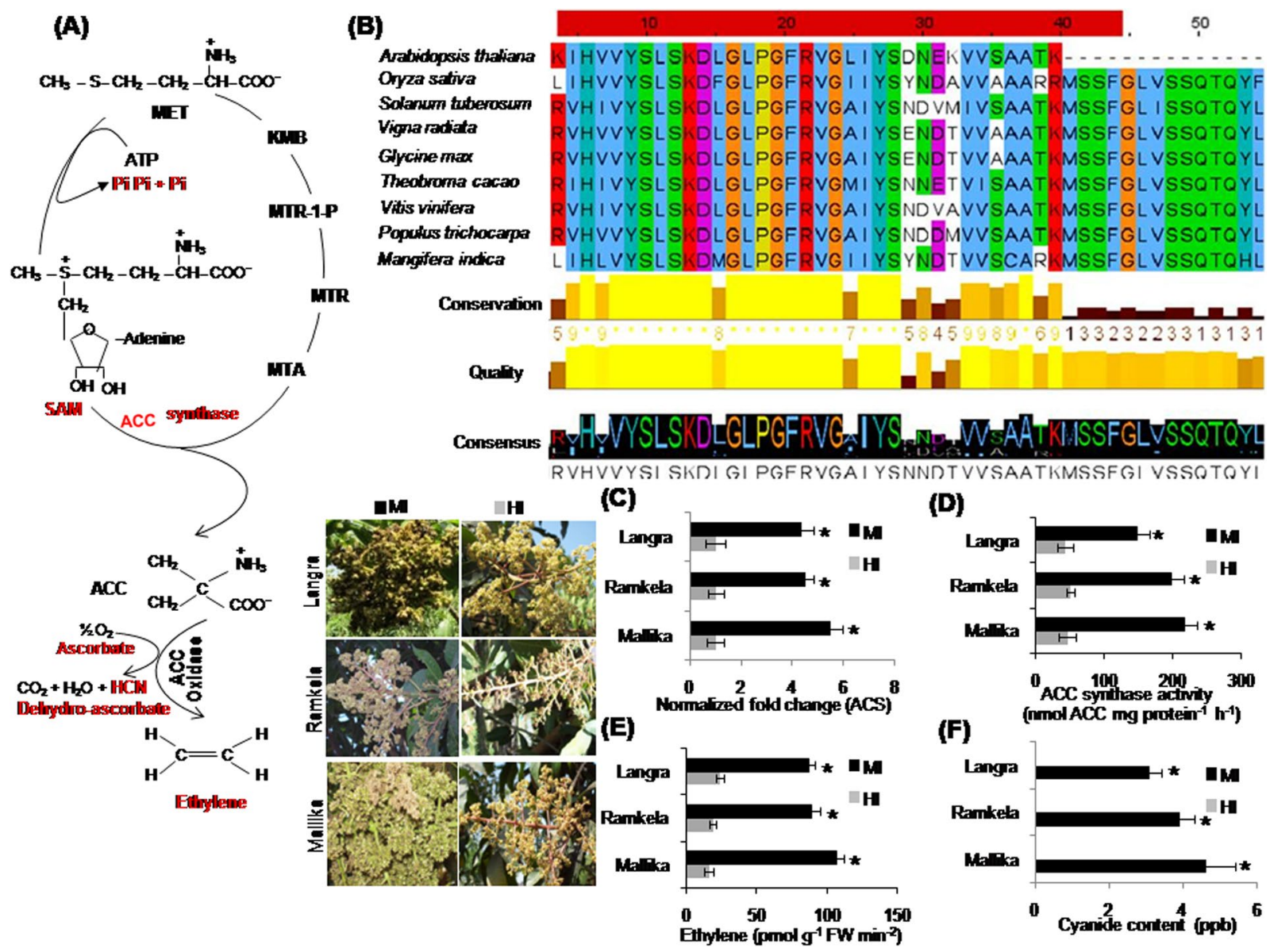

Figure 1. Ethylene biosynthesis, amino acid sequence alignment for 1-aminocyclopropane-1-carboxylic acid $(A C S)$, and endogenous ACS transcript level, ACS enzyme activity and ethylene content in mango inflorescence. Ethylene biosynthesis in mango and regulatory ACC synthase enzyme and byproducts (ascorbate, inorganic phosphate, methionine and cyanide). (A) The amino acid sequence alignment of ACS gene of plant species. s(B) The endogenous transcript levels of ACS. (C) ACC synthase enzyme activity (nmol ACC mg protein ${ }^{-1} \mathrm{~h}^{-1}$ ) (D)

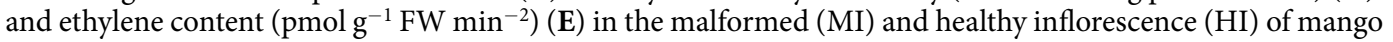
cultivars (Mk, Rk and Ln). Cyanide content (ppb) in MI (F) of mango cultivars while cyanide content in HI was at undetectable levels. The MI and HI of Mk, Rk and Ln are shown on the left side of the bar diagrams. Data represent means \pm SE of at least 3 replicates. '*'Indicates a significant difference between the malformed and healthy inflorescence at the 0.05 level of significance.

(9.78, 9.83 and $10.18 \mu$ mole $\mathrm{g}^{-1} \mathrm{FW}$ ) (Fig. 3B). Moreover, the corresponding ascorbate/dehydroascorbate acid (ASA/DHA) ratio ranged between 0.4-1.1 in MI, whereas it was between 2.58-2.98 in HI of all three mango cultivars (Fig. 3C), respectively. The MI of the three cultivars showed a significant decrease in the activity of dehydroascorbate reductase (DHAR) $\left(5.6,5.1\right.$ and $6.3 \mu$ mole ASA $\mathrm{mg}^{-1}$ protein $\mathrm{min}^{-1}$ ) as compared with $\mathrm{HI}(7.1,7.8$ and $8.5 \mu$ mole ASA $\mathrm{mg}^{-1}$ protein $\mathrm{min}^{-1}$ ) of the mango cultivars (Fig. 3D).

Endogenous glutathione content and glutathione reductase activity. Reduced glutathione (GSH) levels in the MI of Mk, Rk and Ln, were respectively 9.06, 10.94 and $11.58 \mu \mathrm{mol} \mathrm{g}{ }^{-1} \mathrm{FW}$, which was significantly lower than their $\mathrm{HI}$ levels of $15.28,15.53$, and $16.28 \mu \mathrm{mol} \mathrm{g}{ }^{-1} \mathrm{FW}$, respectively (Fig. 4A). Glutathione reductase (GR) activity was also comparatively lower in $\mathrm{MI}\left(4,4.75\right.$ and $4.9 \mathrm{U} \mathrm{mg}^{-1}$ protein $\left.\mathrm{min}^{-1}\right)$ as compared with $\mathrm{HI}$ (8.54, 5.5 and $6.23 \mathrm{U} \mathrm{mg}^{-1}$ protein $\mathrm{min}^{-1}$ ) in all the three mango cultivars (Fig. 4B).

Endogenous $\beta$-CAS transcript level, $\beta$-CAS activity, and unmetabolized cyanide. The multiple alignments of the amino acid sequence of the $\beta$-CAS of various plant species revealed conserved regions of 10-48 amino acids (Fig. 5A). The $\beta$-CAS transcripts in the MI of Mk, Rk and Ln cultivars were 0.71-, 0.19-, and 0.156 -fold down-regulated as compared with similar observation in HI (Fig. 5B). The $\beta$-CAS enzyme, which scavenges potentially toxic cyanide $(\mathrm{HCN})$ in plants by utilizing L-cysteine and giving rise to $\beta$-cyano-L-alanine (Fig. 5C), was significantly lower in MI than HI in the mango cultivars (Fig. 5D). ACC is oxidized to ethylene with the release of a stoichiometrically equivalent amount of hydrogen cyanide (Fig. 5E). We observed 4.9, 4.1 and 3.3 ppb un-metabolized $\mathrm{HCN}$ in the MI of Mk, Rk and Ln respectively, but we did not detect $\mathrm{HCN}$ in $\mathrm{HI}$ (Fig. 5E). 


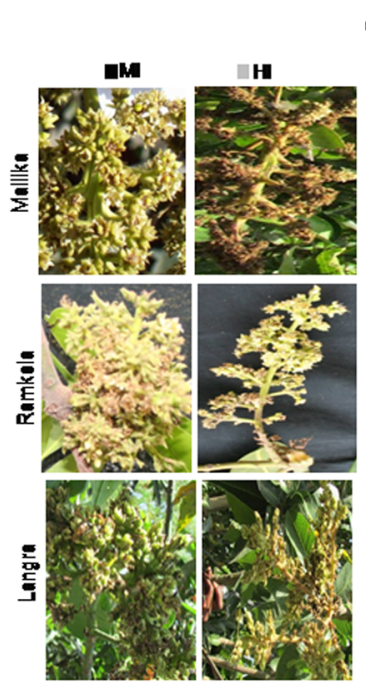

(A)
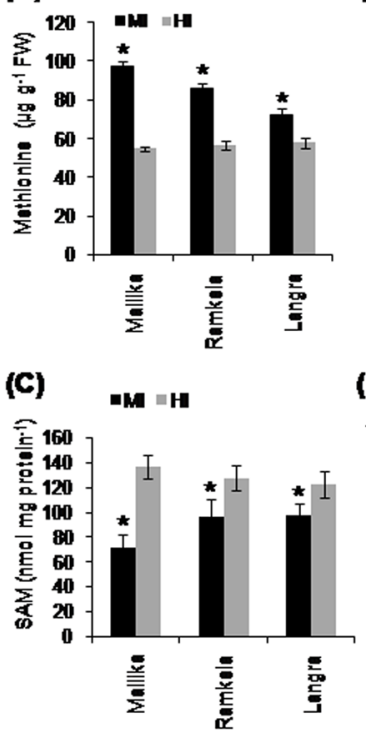

(B)

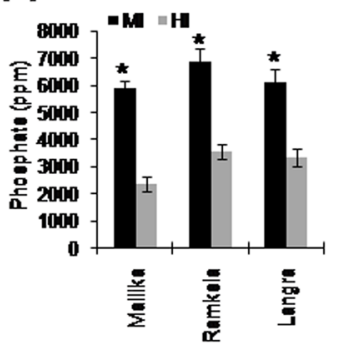

(D)

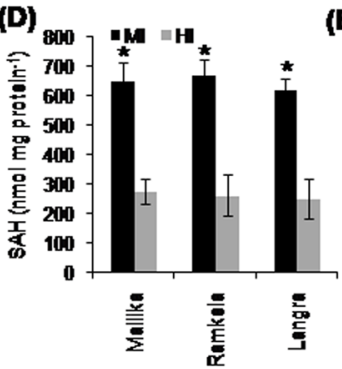

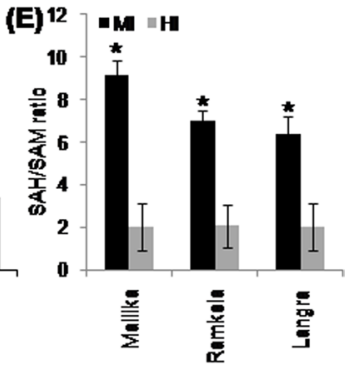

Figure 2. Endogenous methionine, phosphate, S-adenosyl-L-methionine (SAM), S-adenosyl-L-homocysteine (SAH) content and the ratio of SAH/SAM in in mango inflorescence. The malformed and healthy inflorescence of mango cultivars including $\mathrm{Mk}, \mathrm{Rk}$ and $\mathrm{Ln}$ were collected to quantify the endogenous methionine content $\left(\mu \mathrm{g} \mathrm{g}^{-1} \mathrm{FW}\right)(\mathbf{A})$ and phosphate level (ppm). (B) The endogenous level of S-adenosyl-L-methionine (SAM) $\left(\right.$ nmol mg protein $\left.{ }^{-1}\right)(\mathbf{C})$ the endogenous content of S-adenosyl-L-homocysteine (SAH) (D) and S-adenosyl-Lmethionine/S-adenosyl-L-homocysteine (SAH/SAM) ratio (E) in the malformed (MI) and healthy (HI) floral tissue of mango inflorescence of Mk, Rk and Ln. The MI and $\mathrm{HI}$ of Mk, Rk and Ln are shown on the left side of the bar diagrams. Data represent means \pm SE of at least 3 replicates. '*'Indicates a significant difference between the malformed and healthy inflorescence at the 0.05 level of significance.

Transmission electron microscopy shows ultrastructure of gum resin ducts and cellular organelles. We observed excessive gum-resinosis in the malformed floral tissues (MI) of the mango cultivar Rk as compared with healthy floral tissues (HI); therefore, we used TEM to identify various stages in the development of gum resin ducts in both MI and $\mathrm{HI}$ tissues. In the malformed sections, at the initiation stage, the central cell (Fig. 6A) completely disintegrated and dissolved to form a connection between the duct lumen and intercellular spaces surrounding the duct lumen (Fig. 6B) compared with the healthy cells (Fig. 6E). The differentiated cytoplasm of the epithelial cells in MI was dense and dark-stained compared with their healthy counterparts. The cells surrounding the lumen enlarged to form corner lysigenous spaces in MI. The endoplasmic reticulum (ER) in the TEM sections of healthy floral tissues was mostly rough with a continuous array of ribosomes and polysomes. RER profiles were concentrated near the inner tangential wall (Fig. 6B). The epithelial cells surrounding the lumen showed dark cytoplasm and black mitochondria in MI (Fig. 6C,D) compared with HI, which showed normal cytoplasm and healthy cellular organelles, for example, mitochondria and chloroplast (Fig. 6E,F). In the MI, the epithelial cells lining the gum resin canal were thicker and disorganized, and the vacuoles showed an increase in size and number. The mitochondria and chloroplast of the malformed tissues were deformed and blackened, and their number was significantly lower in MI than HI. We also observed a significantly higher number of ribosomes in MI (Table 1).

Dose-response of ethrel and ethylene inhibitors on the incidence of inflorescence malformation. The foliar application of ethrel $(0.0,50,100$ and $200 \mathrm{ppm})$ on inflorescences of mango cultivars during 2009 and 2010 showed that high ethrel concentrations induced malformed necrotic cells in mango inflorescence of $\mathrm{Mk}, \mathrm{Rk}$ and $\mathrm{Ln}$ in both years. The response was maximum at a concentration of $200 \mathrm{ppm}$ of ethrel. Conversely, the response to a specific ethrel concentration and incidence of necrosis was not consistent for the same cultivar in two different flowering seasons (2009 and 2010). Interestingly, the trend of increasing concentration of ethrel50, 100 and $200 \mathrm{ppm}$ reflected the increasing per cent of malformed necrotic inflorescence (Table 2).

We used two ethylene inhibitors $\mathrm{AgNO}_{3}$ and $\mathrm{CoCl}_{2}$ to treat mango inflorescences of $\mathrm{Mk}$, $\mathrm{Rk}$, and $\mathrm{Ln}$ cultivars (Tables 3 and 4). Increasing the concentration (from 50 to $800 \mathrm{ppm}$ ) of $\mathrm{AgNO}_{3}$ and $\mathrm{CoCl}_{2}$ gradually reduced the percent malformed necrotic inflorescence in all tested cultivars of mango- $\mathrm{Mk}$, Rk, and Ln.

Ethrel induced percentage of malformed necrotic inflorescence at $400 \mathrm{ppm}$, and the response was the most pronounced in cultivar $\mathrm{Mk}$ followed by $\mathrm{Rk}$ and $\mathrm{Ln}$. Interestingly, inflorescences sprayed with high concentrations of $\mathrm{AgNO}_{3}(>400 \mathrm{ppm})$ did not show any necrosis indicating that specific concentrations of $\mathrm{AgNO}_{3}$ were highly effective in controlling the incidence of malformed necrotic cells (Table 3). Similarly, high concentrations (1000 $\mathrm{ppm}$ ) of $\mathrm{CoCl}_{2}$ significantly reduced necrotic inflorescence in mango cultivars (Table 4). 
(A)

$$
\mathrm{ACC}+\mathrm{O}_{2}+\text { Ascoibste } \underset{\mathrm{ACC} \text { oxidase }}{\stackrel{\mathrm{Fe}^{2+}}{\longrightarrow}} \mathrm{C}_{2} \mathrm{H}_{4}+\mathrm{CO}_{2}+\mathrm{Del} \text { yduasconbate }+\mathrm{HCN}+\mathrm{H}_{2} \mathrm{O}
$$

(B)

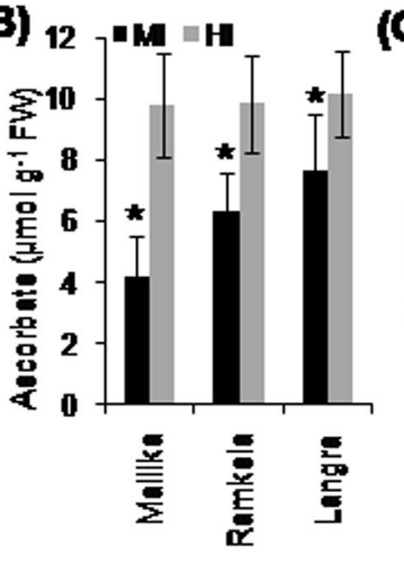

(C)

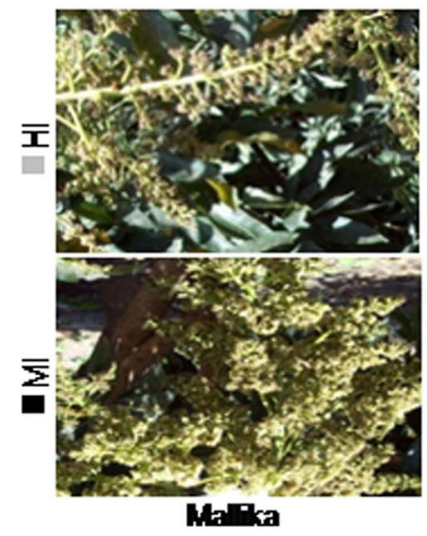

C) 4

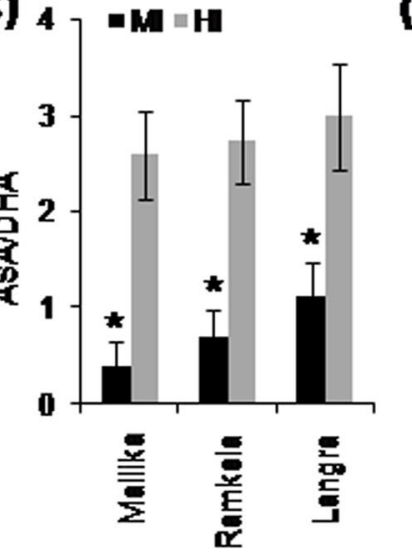

(D)

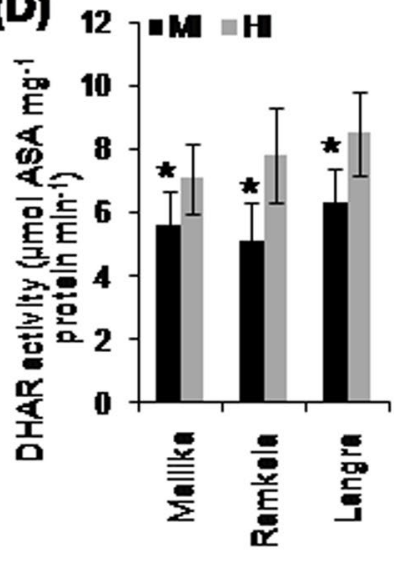

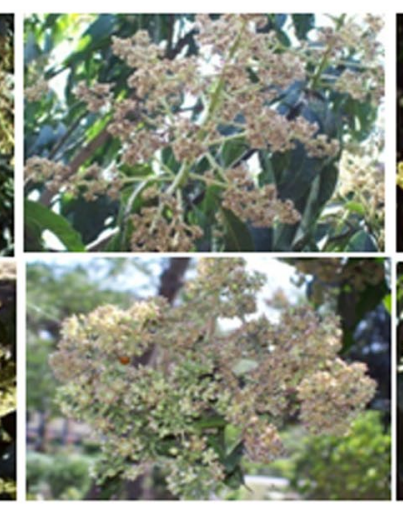

Ramkela

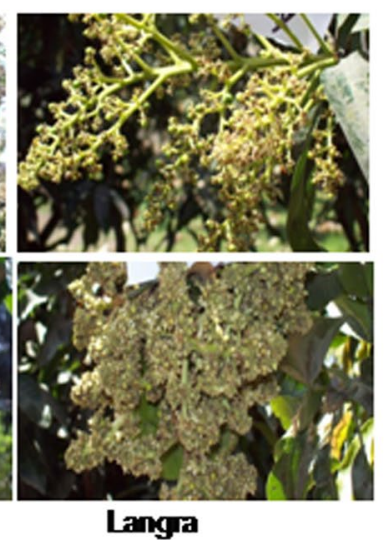

Figure 3. Ascorbate level, dehydroascorbate reductase and ASA/DHA ratio in mango inflorescence. The conversion of 1-aminocyclopropane-1-carboxylic acid (ACC) to ethylene catalyzed by ACC oxidase (ACO) requiring $\mathrm{Fe}^{2+}$ and ascorbate as cofactor/cosubstrate. (A) The endogenous levels of ascorbate (ASA) ( $\mu \mathrm{mole}^{-1}$ FW) (B) the corresponding ascorbate/dehydroascorbate acid (ASA/DHA) ratio (C) and the activity ( $\mu$ mole ASA $\mathrm{mg}^{-1}$ protein $\mathrm{min}^{-1}$ ) of dehydroascorbate reductase (DHAR) enzyme (D) in the malformed (MI) and healthy inflorescence (HI) of mango cultivars $\mathrm{Mk}, \mathrm{Rk}$ and $\mathrm{Ln}$. The MI and $\mathrm{HI}$ of Mk, Rk and Ln are shown underneath the bar diagrams. Data represent means $\pm S E$ of at least 3 replicates. ' $*$ 'Indicates a significant difference between the malformed and healthy inflorescence at the 0.05 level of significance.

\section{Discussion}

Malformation of mango inflorescences (MMI) threatens mango productivity and causes significant damage to the mango industry ${ }^{25,36}$. Although Fusarium species have been implicated in malformation, the etiology of this disease remains obscure and effective control measures have not yet been identified ${ }^{4,11,25}$. Moreover, fungicides and other tested chemicals have not proved effective in controlling the disease ${ }^{37,38}$. Our previous study revealed higher ethylene levels in malformed vegetative and floral mango tissues as compared to the healthy plants ${ }^{7}$. Cyanide causes abnormal development of flowers and deformation of reproductive organs leading to loss of function $^{7,8,15,25}$. F. mangiferae increases the endogenous pool of cyanide and ethylene probably by contributing towards its synthesis 9 . Moreover, F. mangiferae may act through malformation inducing principle (MIP) rather than the toxic principle ${ }^{39}$, suggesting that cyanide can be an etiological agent of mango malformation. Here, we discuss a comprehensive role of cyanide derived from ethylene biosynthesis in the development of mango malformation.

ACS is a key enzyme of regulating synthesis of cyanide, a co-product of ethylene. ACSs, encoded by a multigene family, is differentially expressed during plant developmental processes and regulated by various environmental and hormonal signals ${ }^{40}$. ACS genes have been studied in diverse plant species ${ }^{41}$. The amino acid sequence alignment of ACS of diverse plant species showed conserved regions of 4-44 amino acids (Fig. 1A). ACS transcripts were induced in the senescing petals of Dianthus caryophyllus ${ }^{42}$, and increased in the flower buds of Japanese pear (Pyrus pyrifolia Nakai) ${ }^{43}$. ACS transcripts were abundant in both the detached and attached 


\section{(A)}

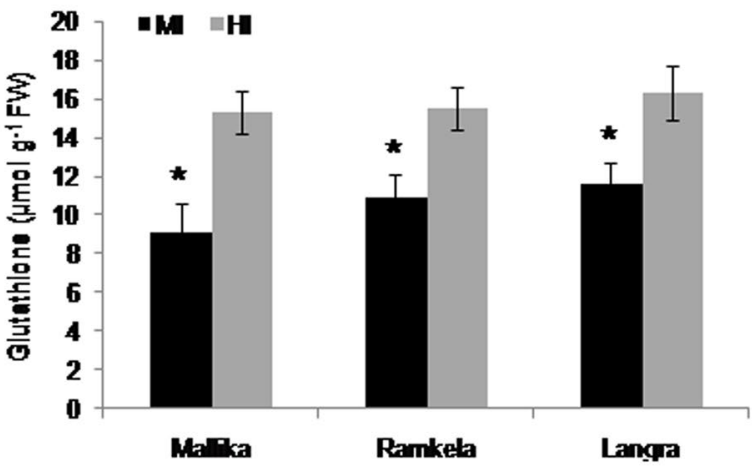

(B)

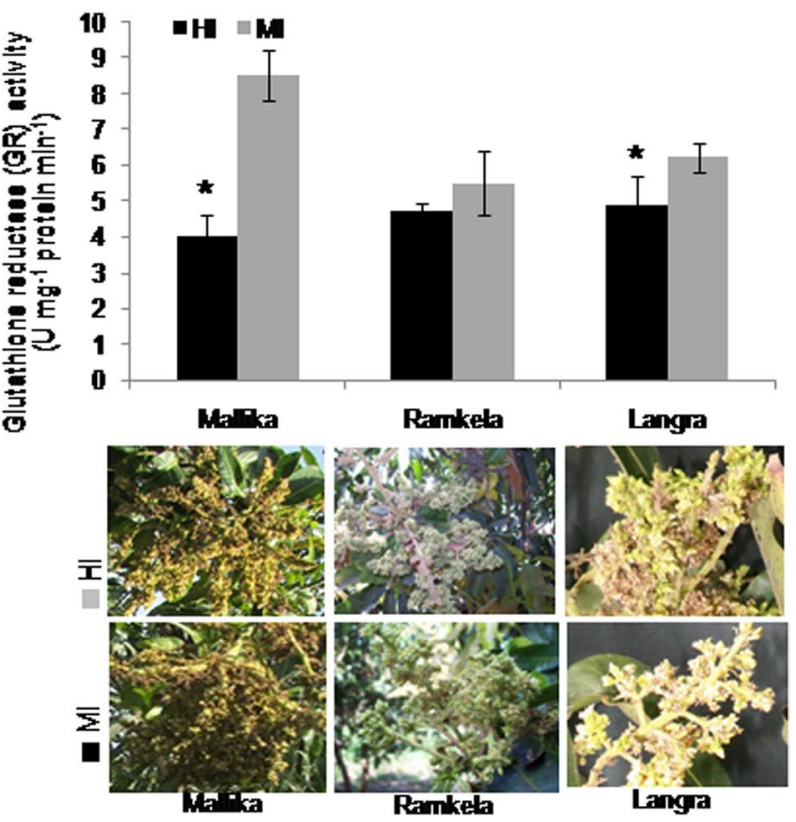

Figure 4. Endogenous content of glutathione and the activity of glutathione reductase in mango inflorescence. The endogenous level of reduced glutathione (GSH) ( $\left.\mu \mathrm{mol} \mathrm{g}{ }^{-1} \mathrm{FW}\right)(\mathbf{A})$ and the activity $\left(\mathrm{U} \mathrm{mg}^{-1}\right.$ protein $\mathrm{min}^{-1}$ ) of glutathione reductase (GR) (B) in the malformed (MI) and healthy inflorescence (HI) of mango cultivars Mk, Rk and Ln. Data represents mean \pm SE of at least 3 replicates. '*'Indicates that the difference between the malformed (MI) and healthy inflorescence (HI) was significant at the 0.05 level of significance. The MI and HI of $\mathrm{Mk}, \mathrm{Rk}$ and $\mathrm{Ln}$ are shown underneath the bar diagrams. Data represent means $\pm \mathrm{SE}$ of at least 3 replicates. '*'Indicates a significant difference between the malformed and healthy inflorescence at the 0.05 level of significance.

carnation petals ${ }^{44}$. Moreover, the ACS transcripts, ACC synthase activity, ethylene and cyanide production in different stages of flower development coincide with flower senescence ${ }^{45}$. Our data showed a relatively higher accumulation of ACS transcripts in MI over HI corroborating the increased ACS activity and elevated cyanide and ethylene levels.

Besides cyanide other important byproducts and/or biomolecules of ethylene synthesis might play an important role in mango malformation. The methionine-ACC pathway for ethylene biosynthesis in plants is well-studied ${ }^{17}$ showing that SAM is converted to ACC and MTA, and MTA is sequentially recycled to methionine ${ }^{46}$. Thus, a small quantity of methionine in the tissue can produce a considerable amount of $\mathrm{ACC}^{47}$ indicating that additional methionine is not required to synthesize cyanide and ethylene ${ }^{29}$, which might gradually accumulate within the tissue. The comparatively higher level of methionine in MI than HI of mango plants suggest increased rate of cyanide and ethylene production in the malformed tissues under the hypersensitive stress response. Thus, continuous synthesis of cyanide and ethylene liberates considerable inorganic phosphorous (PPi and $\mathrm{Pi}$ ) in the step catalyzed by SAM synthetase $\mathrm{e}^{25}$, and excessive Pi causes the formation of shallow roots reducing plant growth and meristematic activity ${ }^{48}$. Similarly, we have found higher phosphorus concentrations in MI than HI suggesting another link to malformation.

SAM, a vital biological methyl donor, participates in the methylation of biomolecules/volatiles and acts as a substrate for the synthesis of cyanide and ethylene, spermidine, spermine and thermospermine, and nicotianamine and biotin ${ }^{49}$. SAM, a methyl donor in the transmethylation reactions, induces S-adenosyl-L-homocysteine 
(A)

\section{Arabidopsis thaliana \\ Oryza sativa \\ Hevea brasiliensis \\ Cucumis sativus \\ Glycine max \\ Vitis vinifera}

\section{Conservation}

Quality

Consensus
20

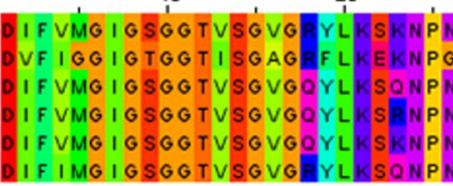

F IMG I GSGGTVSGVGRY

if

(1)
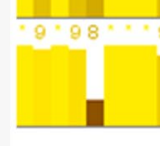

(C)

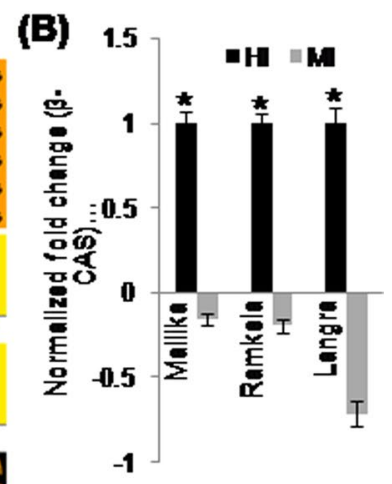

\begin{tabular}{|c|c|c|c|c|c|c|}
\hline & & & B-cyanoalanine synthase & & & \\
\hline $\begin{array}{r}\mathrm{HS}_{2} \mathrm{CH}_{2} \mathrm{CH}_{\left(\mathrm{NH}_{2}\right) \mathrm{COOH}} \\
\text { L-cystein }\end{array}$ & + & $\begin{array}{l}\text { HCN } \\
\text { Cyanide }\end{array}$ & $\longrightarrow$ & 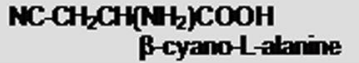 & + & $\mathrm{H}_{2} \mathrm{~S}$ Sulfide \\
\hline
\end{tabular}

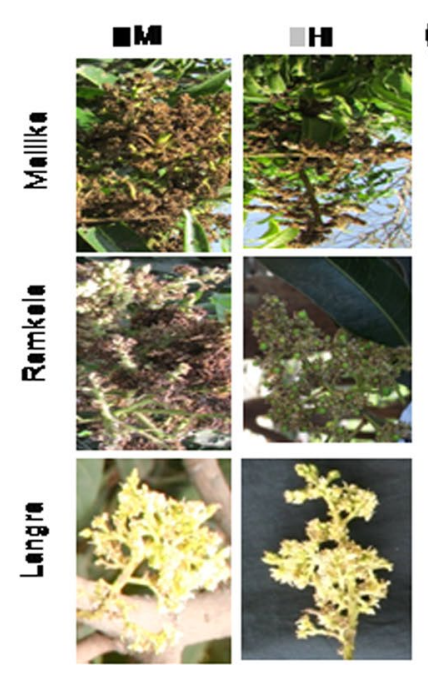

(D)

(E)
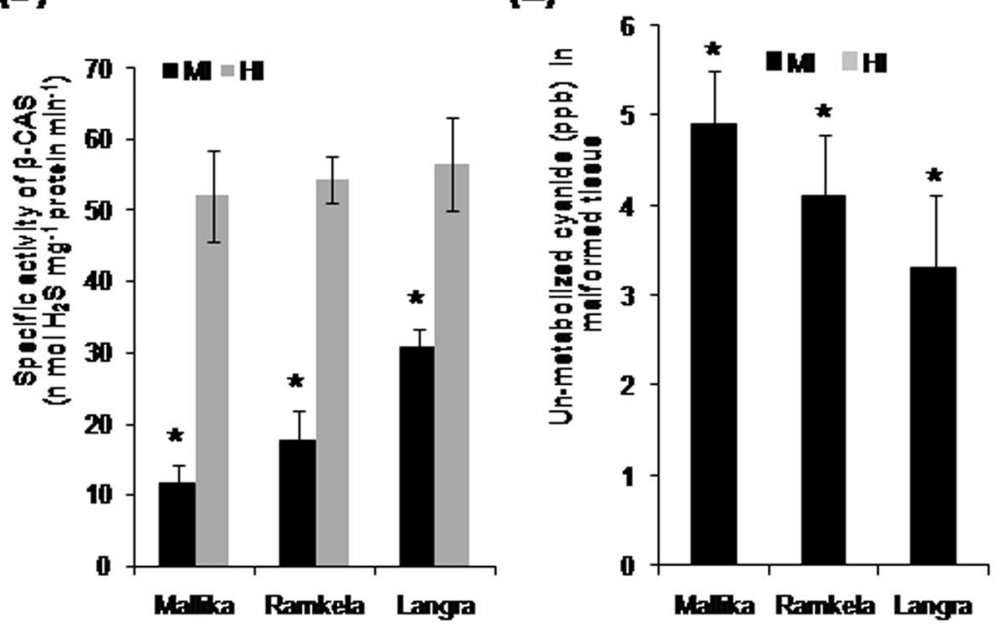

Figure 5. Amino acid sequence alignment of $\beta$-cyanoalanine synthase gene of various plant species, and the endogenous $\beta$-cyanoalanine synthase transcript level, $\beta$-cyanoalanine synthase activity, un-metabolized cyanide content and succinate dehydrogenase activity in mango inflorescence. The multiple alignment of amino acid sequence of $\beta$-cyanoalanine synthase $(\beta-C A S)$ gene of plant species (The amino acid sequence of $\beta$-cyanoalanine synthase is not available yet in mango genome sequence). (A) The $\beta$-CAS transcripts level in the malformed (MI) and healthy inflorescence (HI) of mango plants of tested cultivars. (B) The $\beta$-CAS enzyme catalyzes cyanide (HCN) detoxification by utilizing $\mathrm{L}$ - cystein, which gives rise to $\beta$-cyano-L-alanine. (C) The endogenous $\beta$-CAS enzyme activity $\left(\mathrm{nmol} \mathrm{H}_{2} \mathrm{~S} \mathrm{mg}^{-1}\right.$ protein $\mathrm{min}^{-1}(\mathbf{D})$ in the malformed (MI) and healthy inflorescence (HI) of mango cultivars Mk, Rk and Ln. The endogenous un-metabolized cyanide (HCN) level (ppb) (E) in the MI of mango cultivars, however cyanide content in HI was at undetectable levels. The MI and $\mathrm{HI}$ of Mk, Rk and Ln are shown on the left side of the bar diagrams. Data represents mean $\pm \mathrm{SE}$ of at least 3 replicates. '*'Indicates a significant difference between the malformed and healthy inflorescence at the 0.05 level of significance.

(SAH) formation, which in turn metabolizes to methionine via homocysteine in SAM-dependent methylations ${ }^{50}$. Again, we have demonstrated a lower SAM content and higher SAH/SAM ratio in MI than HI.

ASA, a -water-soluble antioxidant, significantly mitigates oxidative damage $e^{51}$, and is a cofactor for many enzymes including ACC oxidase ${ }^{52}$, which catalyzes the final step in cyanide and ethylene biosynthetic pathway ${ }^{53}$. Our data showed low levels of ASA in MI indicating an increased rate of cyanide and ethylene production, which consumes ASA from a constant 'endogenous ASA pool' in MI. ASA and DHA play a crucial role in redox homeostasis in the cell ${ }^{54}$, and the ratio of ASA/DHA governs the ability of plant cells to remove reactive oxygen species (ROS) to enhance protection from oxidative damage $\mathrm{e}^{55}$. According to our results, a reduced DHAR activity in MI might cause a lower ASA/DHA ratio and damage cells. ASA and GSH play an essential role in defensive processes against oxidative damage by generated ROS $^{56}$. Recycling of GSH is catalyzed by GR, which reduces GSSG via $\mathrm{NADPH}^{57}$. Cyanide and ethylene alter the ascorbic AA-GSH levels in S. lycopersicum ${ }^{58}$. ASA synthesis and endogenous levels are down-regulated by cyanide and ethylene ${ }^{59,60}$, which in turn affect the GSH levels. Thus, a 

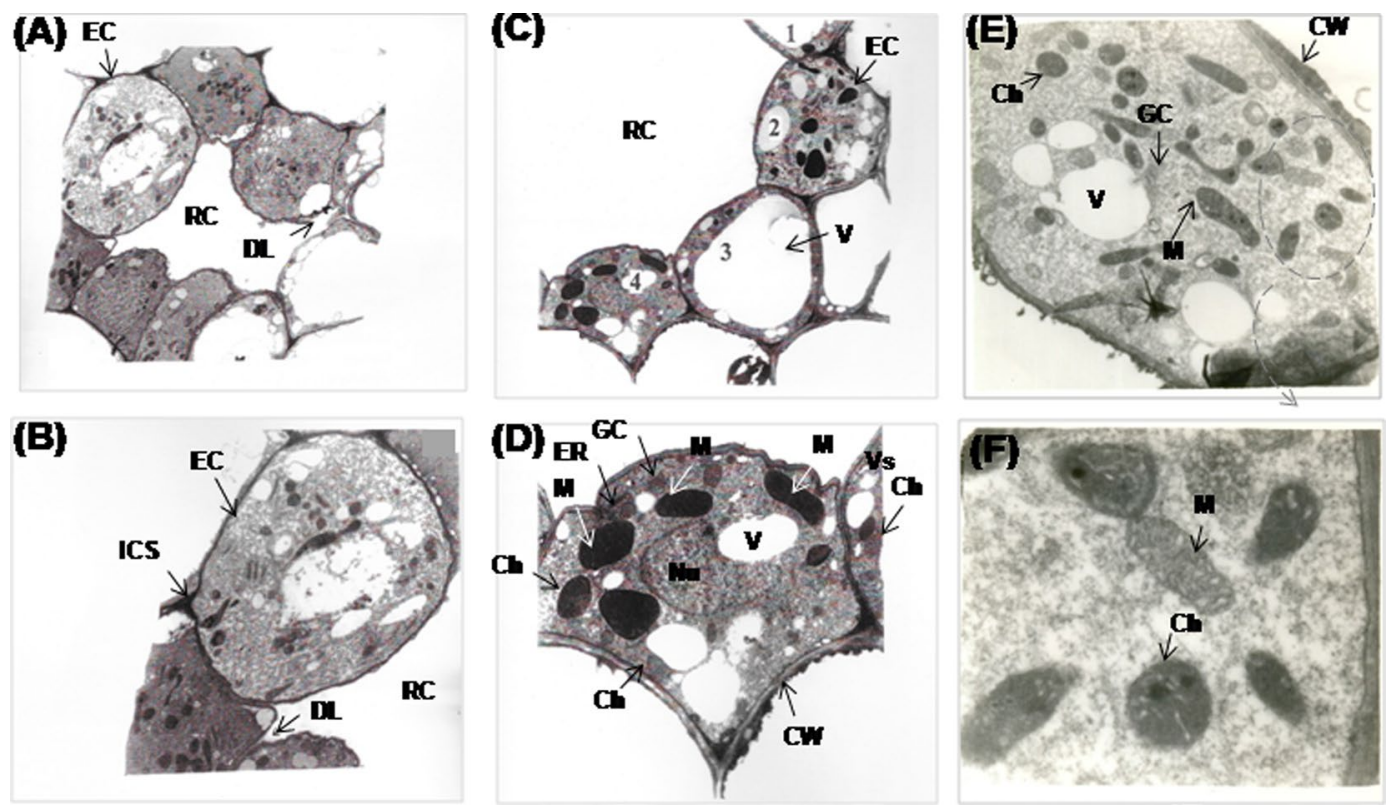

Figure 6. Transmission electron micrograph of malformed and healthy floral tissues of mango cultivar Rk. The cross-section of malformed floral tissues shows a completely disintegrated central cell at the stage of formation of resin canal. The cell-wall regions of the central cell are completely dissolved forming the duct lumen (X 1150). (A) Higher magnification view of a cell showed a connection between duct lumen and intercellular space (X 1950). (B) The cross-section of malformed floral tissues shows epithelial cells at various stages of differentiation. Cells possess dark cytoplasm and intact cell organelles while mitochondria appear black in the section (X1150). (C) Higher magnification view of malformed cell in which the large number of vacuoles are visible in the highly osmiophilic cytoplasm and the mitochondria appears black and irregularly shaped. (X1950). (D) The cross-section of healthy floral tissues showing healthy cell organelles (X1950) (E) and enlarged view revealing normal mitochondria and chloroplast. (F) RC, resin canal; EC, epithelial cell; DL, duct lumen; ICS, intercellular space; CW, cell wall; $\mathrm{Ch}$, chloroplast; $\mathrm{M}$, mitochondrion; Nu, nucleolus; V, vacuole; Vs, small vesicle; GC Golgi complex.

\begin{tabular}{|l|l|l|}
\hline \multirow{2}{*}{ Characteristic } & Transmission electron microscopy (TEM) \\
\cline { 2 - 3 } & HI & MI \\
\hline Cell wall & thin & thick \\
\hline Central vacuole & normal & Enlarged, number increased \\
\hline Mitochondria & $\begin{array}{l}\text { Size is variable both small } \\
\text { and large }\end{array}$ & $\begin{array}{l}\text { Disorganized, blackened and their } \\
\text { number decreased }\end{array}$ \\
\hline Chloroplast & normal & disrupted \\
\hline Ribosomes & normal & Number increases \\
\hline $\begin{array}{l}\text { Epithelial cells lining the gum } \\
\text { resin canal }\end{array}$ & normal & Thicker, disorganized and blackened \\
\hline
\end{tabular}

Table 1. Transmission electron microscopy of malformed (MI) and healthy (HI) floral tissue of mango cultivar Rk.

significantly lower GR activity and reduced GSH content in mango MI in our study can be attributed to the overproduction of cyanide and ethylene.

A ubiquitous supply of cyanide in higher plants is mainly due to ethylene biosynthesis. Cyanide is a co-product of the production of ethylene from $\mathrm{ACC}^{61}$, which is metabolized via the $\beta$-cyanoalanine pathway. The $\beta$-CAS enzyme, ubiquitously found in every plant tissue, catalyzes the reaction between L-cysteine and HCN to yield $\beta$-cyanoalanine and hydrogen sulfide $\left(\mathrm{H}_{2} \mathrm{~S}\right)^{62}$. $\beta$-CAS genes have now been studied in many plant species including rice ${ }^{35,63,64}$. $\beta$-CAS activity was studied in the leaves and seedlings of various plant ${ }^{32,65}$ and was found to increase in ethylene-treated flowers ${ }^{66}$. $\beta$-CAS functions in cyanide detoxification in higher plants including rice and soybean ${ }^{35,67}$ suggesting a negative correlation between cyanide accumulation and $\beta$-CAS expression ${ }^{68,69}$. In our study, the lower $\beta$-CAS transcript in MI than $\mathrm{HI}$ of mango validates the accumulation of additional un-metabolized cyanide. Increased cyanide levels may block electron transport via cytochrome oxidase (complex IV) and prevent ATP formation. Cyanide and ethylene alter various growth and metabolic processes of plants $^{70}$ and cause the development of resin canals and the surrounding epithelial cells ${ }^{71}$. Cyanide treated flower pedicels of Nicotiana tabacum affects the surface area and relative volume of cell organelles and their number ${ }^{72}$. Ethrel treatment has been shown to exhibit decreased flower development by increasing cyanide level ${ }^{73}$. Cyanide 


\begin{tabular}{|c|c|c|c|c|c|c|c|c|}
\hline \multirow{4}{*}{$\begin{array}{l}\text { Mango } \\
\text { cultivars }\end{array}$} & \multicolumn{8}{|c|}{ Inflorescence necrosis (\%) } \\
\hline & \multicolumn{4}{|l|}{2009} & \multicolumn{4}{|l|}{2010} \\
\hline & E0 & E50 & E100 & E200 & E0 & E50 & E100 & E200 \\
\hline & Mean \pm SE & Mean \pm SE & Mean \pm SE & Mean \pm SE & Mean \pm SE & Mean \pm SE & Mean \pm SE & Mean \pm SE \\
\hline Mallika (Mk) & $34.01 \pm 1.22 \mathrm{gh}$ & $36.00 \pm 0.69 \mathrm{fg}$ & $51.04 \pm 1.66 \mathrm{~b}$ & $52.00 \pm 3.33 \mathrm{ab}$ & $28.00 \pm 1.1 \mathrm{f}$ & $47.00 \pm 1.49 \mathrm{~cd}$ & $49.03 \pm 1.5 \mathrm{bcd}$ & $56.00 \pm 1.58 \mathrm{a}$ \\
\hline Ramkela (Rk) & $31.00 \pm 1.02 \mathrm{~h}$ & $41.00 \pm 1.62 \mathrm{de}$ & $49.02 \pm 0.67 b c$ & $56.01 \pm 0.67 \mathrm{a}$ & $30.03 \pm 1.02 \mathrm{f}$ & $39.01 \pm 1.0 \mathrm{e}$ & $51.04 \pm 1.65 \mathrm{bc}$ & $52.00 \pm 1.03 \mathrm{ab}$ \\
\hline Langra (Ln) & $35.00 \pm 0.67 \mathrm{gh}$ & $40.00 \pm 1.33 \mathrm{ef}$ & $45.00 \pm 1.66 \mathrm{~cd}$ & $50.00 \pm 1.09 \mathrm{~b}$ & $39.00 \pm 1.33 \mathrm{e}$ & $45.00 \pm 1.67 \mathrm{~d}$ & $50.00 \pm 1.48 \mathrm{bc}$ & $48.00 \pm 0.99 \mathrm{bcd}$ \\
\hline
\end{tabular}

Table 2. Dose response of ethrel in the development on inflorescence necrosis of mango cultivars. Foliar application of different concentrations of ethrel was evaluated in two consecutive years of 2009 and 2010. The data in the table are mean \pm SE. Means followed by different letters within a row are significantly different in Tukey's Post hoc HSD test at $P<0.05$. The different concentrations of ethrel are E0 $=0.0 \mathrm{ppm}$ (control); E50 $=50$ ppm; E100 = 100 ppm; E200 = 200 ppm.

\begin{tabular}{|l|l|l|l|}
\hline \multirow{2}{*}{$\begin{array}{l}\text { Silver nitrate } \\
(\mathrm{ppm})\end{array}$} & \multicolumn{3}{|l|}{ Malformed necrotic inflorescence (\%) } \\
\cline { 2 - 4 } & Mallika (Mk) & Ramkela (Rk) & Langra (Ln) \\
\cline { 2 - 4 } Control & $72.5 \pm 1.18 \mathrm{a}$ & $69.5 \pm 1.61 \mathrm{ab}$ & $69.0 \pm 2.68 \mathrm{ab}$ \\
\hline 50 & $68.7 \pm 1.98 \mathrm{ab}$ & $69.0 \pm 2.07 \mathrm{ab}$ & $67.6 \pm 1.64 \mathrm{ab}$ \\
\hline 75 & $67.0 \pm 1.54 \mathrm{~b}$ & $69.0 \pm 2.25 \mathrm{ab}$ & $65.0 \pm 1.37 \mathrm{bc}$ \\
\hline 100 & $55.9 \pm 0.56 \mathrm{de}$ & $57.6 \pm 0.34 \mathrm{de}$ & $60.4 \pm 0.39 \mathrm{~cd}$ \\
\hline 150 & $49.3 \pm 1.71 \mathrm{f}$ & $52.3 \pm 1.30 \mathrm{ef}$ & $54.2 \pm 2.84 \mathrm{ef}$ \\
\hline 200 & $36.6 \pm 0.98 \mathrm{~g}$ & $50.0 \pm 1.79 \mathrm{f}$ & $49.0 \pm 1.61 \mathrm{f}$ \\
\hline 250 & $30.5 \pm 1.37 \mathrm{~h}$ & $48.5 \pm 0.45 \mathrm{f}$ & $49.2 \pm 0.94 \mathrm{f}$ \\
\hline 300 & $19.2 \pm 3.61 \mathrm{j}$ & $40.7 \pm 0.81 \mathrm{~g}$ & $39.0 \pm 3.80 \mathrm{~g}$ \\
\hline 400 & $7.0 \pm 2.73 \mathrm{k}$ & $23.0 \pm 2.68 \mathrm{ij}$ & $24.8 \pm 0.8 \mathrm{i}$ \\
\hline 500 & $0 \pm 0 \mathrm{l}$ & $0 \pm 0 \mathrm{l}$ & $9.0 \pm 2.87 \mathrm{k}$ \\
\hline 600 & $0 \pm 0 \mathrm{l}$ & $0 \pm 0 \mathrm{l}$ & $0 \pm 0 \mathrm{l}$ \\
\hline 800 & $0 \pm 0 \mathrm{l}$ & $0 \pm 0 \mathrm{l}$ & $0 \pm 0 \mathrm{l}$ \\
\hline
\end{tabular}

Table 3. Dose response of silver nitrate $\left(\mathrm{AgNO}_{3}\right)$ on inflorescence necrosis of mango cultivars. Foliar application of silver nitrate in concentration raging from 50 to $800 \mathrm{ppm}$ was evaluated during flowering season of 2013. The data in the table are mean \pm SE. Means followed by different letters within a row are significantly different in Tukey's Post hoc HSD test at $P<0.05$.

\begin{tabular}{|l|l|l|l|}
\hline \multirow{2}{*}{$\begin{array}{l}\text { Silver nitrate } \\
(\mathbf{p p m})\end{array}$} & Malformed necrotic inflorescence (\%) & Langra (Ln) \\
\cline { 2 - 4 } & Mallika (Mk) & Ramkela (Rk) & Mean \pm SE \\
\hline Control & $71.2 \pm 2.78 \mathrm{a}$ & Mean \pm SE & $69.0 \pm 1.26 \mathrm{abcd}$ \\
\hline 25 & $70.75 \pm 2.41 \mathrm{ab}$ & $70.4 \pm 1.55 \mathrm{abc}$ & $68.0 \pm 1.27 \mathrm{abcd}$ \\
\hline 50 & $70.0 \pm 1.81 \mathrm{abc}$ & $69.8 \pm 1.19 \mathrm{abcd}$ & $68.5 \pm 1.50 \mathrm{abcd}$ \\
\hline 75 & $69.4 \pm 2.95 \mathrm{abcd}$ & $70.0 \pm 2.45 \mathrm{abc}$ & $66.97 \pm 1.37 \mathrm{abcde}$ \\
\hline 100 & $70.3 \pm 2.19 \mathrm{abc}$ & $68.8 \pm 1.48 \mathrm{abcd}$ & $65.0 \pm 1.94 \mathrm{abcdef}$ \\
\hline 150 & $65.0 \pm 2.53 \mathrm{abcdef}$ & $65.0 \pm 2.24 \mathrm{abcdef}$ & $63.63 \pm 0.28 \mathrm{cdef}$ \\
\hline 200 & $64.0 \pm 3.58 \mathrm{bcdef}$ & $66.25 \pm 1.16 \mathrm{abcdef}$ & $60.13 \pm 1.40 \mathrm{efg}$ \\
\hline 300 & $53.0 \pm 2.78 \mathrm{~h}$ & $63.0 \pm 2.73 \mathrm{def}$ & $55.3 \pm 1.07 \mathrm{gh}$ \\
\hline 400 & $43.0 \pm 2.68 \mathrm{i}$ & $59.0 \pm 0.36 \mathrm{fgh}$ & $56.0 \pm 2.37 \mathrm{gh}$ \\
\hline 600 & $31.0 \pm 3.07 \mathrm{j}$ & $60.50 \pm 2.69 \mathrm{efg}$ & $38.65 \pm 3.64 \mathrm{i}$ \\
\hline 800 & $20.0 \pm 2.86 \mathrm{kl}$ & $44.0 \pm 2.55 \mathrm{i}$ & $26.0 \pm 3.89 \mathrm{jk}$ \\
\hline 1000 & $9.0 \pm 1.03 \mathrm{n}$ & $29.8 \pm 0.63 \mathrm{j}$ & $12.8 \pm 0.88 \mathrm{mn}$ \\
\hline
\end{tabular}

Table 4. Dose response of cobalt chloride $\left(\mathrm{CoCl}_{2}\right)$ on inflorescence necrosis of mango cultivars. Foliar application of cobalt chloride in concentration raging from 25 to $1000 \mathrm{ppm}$ was evaluated during flowering season of 2013. The data in the table are mean \pm SE. Means followed by different letters within a row are significantly different in Tukey's Post hoc HSD test at $P<0.05$. 

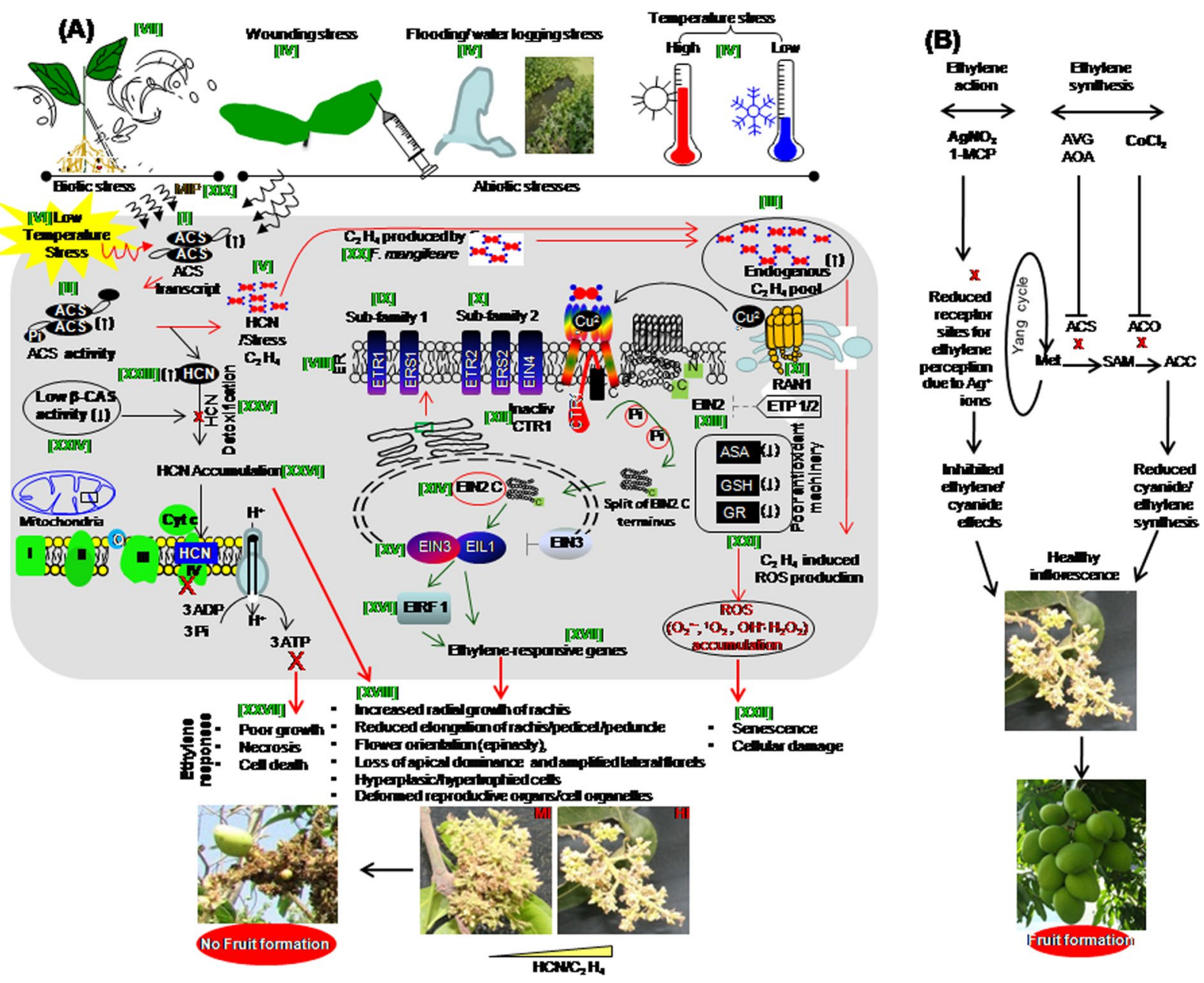

Figure 7. The proposed mechanism for malformation of mango inflorescences (A) and its subsequent management. (B) The induced ACS expression [I] and ACS activity [II] and cyanide and ethylene content [III, XXVI] in response to stress [IV-VIII]. ER [VIII] perceives ethylene by a family of receptors [IX-XI] to inactivate CTR1 [XII]. This leads to dephosphorylation of EIN2 into EIN2 C-terminal [XIII] to induce a transcription cascade of ethylene-responsive genes [XIV] by ERF1 and EIN3/EIL1 [XV-XVII] to show the reponse as malformation symptoms [XVIII]. F. mangiferae increases cyanide and ethylene pool [XIX-XX, XXVI]. The affected antioxidants system [XXI] accumulates ROS [XXII] causing damaging effects. Cyanide accumulated [XXIII] by low activity of $\beta$-CAS [XXIV-XXV] inhibits the complex IV of mitochondrial ETC and ATP formation and causes malformation symptoms [XXVII] (A). Exogenous cobalt chloride $\left(\mathrm{CoCl}_{2}\right)$ and silver nitrate $\left(\mathrm{AgNO}_{3}\right)$ suppresses cyanide/ethylene synthesis and effects to control the disease. (B) $\mathrm{HI}$, healthy inflorescence; MI, malformed inflorescence; MS, mango malformation system; MIP, malformation inducing principle; $\mathrm{ACS}, \mathrm{ACC}$ synthase; $\beta$-CAS, $\beta$-cyanoalanine synthase; $\mathrm{HCN}$, cyanide; $\mathrm{C}_{2} \mathrm{H}_{4}$, ethylene; ER, Endoplasmic reticulum; ETR1, ethylene response 1; ERS1, ethylene response sensor 1; ETR2, ethylene response 2; ERS2, ethylene response sensor 2; EIN2, EIN3, EIN4, ethylene insensitive 2,3,4; RAN1, responsive-toantagonist-1; ETP, EIN2 targeting protein; CTR1, constitutive triple response1; EIL1, ethylene insensitive-like protein 1; ERF, ethylene response factor; ASA, ascorbate; GSH, reduced glutathione; GR, glutathione reductase; ROS, reactive oxygen species; $\mathrm{AgNO}_{3}$, silver nitrate; 1-MCP, 1-methylcyclopropane; AOA, aminooxyacetic acid; AVG, aminoethoxyvinylglycine.

and ethylene acts as a modulator of the membrane structure of cellular organelles including chloroplast and mitochondria ${ }^{74}$. In the present TEM study, cells of malformed inflorescence showing black dead mitochondria were observed. The interlink between programmed cell death and malformation in mango inflorescence has not been defined, however there is indication that ROS as signaling molecules could realize programmed cell death ${ }^{75}$, which might be mediated via cyanide. Our TEM sections of malformed floral tissues showed various stages in the development of resin ducts. Moreover, epithelial cells showed distorted cell organelles in addition to deformed black mitochondria, which could be due to the toxic and adverse effects of cyanide.

Based on our results and previous studies, we propose a model summarizing the role of cyanide in mango malformation (Fig. 7A), and its subsequent management via inhibiting cyanide and ethylene synthesis and action (Fig. 7B). Multiple abiotic and/or biotic stresses influence the basal cyanide production in the 'mango malformation system' (MS) ${ }^{25,38}$ and the 'system other than mango malformation' (SOM) ${ }^{76,77}$. Previous studies show that 
ACS expression is modulated in response to stress in $\mathrm{SOM}^{17,70,78}$, which in turn regulates ethylene and thereby cyanide. Ethylene is perceived at the ER receptors to follow the signal transduction cascade of CTR1 inactivation, a downstream transcriptional cascade of EIN2 C, and the activation ethylene responsive genes ${ }^{79}$.

As shown in Fig. 7A, our study on MS shows that MI have induced ACS expression [I] and ACS activity [II] and an elevated endogenous cyanide/ethylene pool [III, XXVI]. Cyanide and ethylene production in response to stress, for example, wounding, waterlogging and very low and high temperatures [IV] is termed as 'stress induced cyanide/ethylene' $[\mathrm{V}]^{25}$. The stress induced ACS expression corroborates higher levels of cyanide/ethylene in MI under low-temperature stress during winter [VI, XXVI]. Moreover, Fusarium invasion as a wounding stress can induce ethylene synthesis in MS [VII]). Endoplasmic reticulum (ER) [VIII] is the main site of ethylene perception by a family of receptors comprising subfamily-I (ethylene response 1, ETR1; ethylene response sensor 1, ERS1) [IX] and subfamily-II (ethylene response 2, ETR2; ethylene response sensor 2, ERS2; ethylene insensitive 4, EIN4) $[\mathrm{X}]^{80}$. Moreover, $\mathrm{Cu}^{2+}$ (Copper) transporter responsive-to-antagonist-1 (RAN1) deliver the $\mathrm{Cu}^{2+}$, which is required ethylene binding to receptor [XI]. Thus, ethylene receptors are inactivated, and the 'constitutive triple response1 (CTR1) protein kinase' [XII] causes EIN2 dephosphorylation and consequently its cleavage $[\mathrm{XIII}]^{81}$. EIN2 C-terminal section is localized to the nucleus [XIV] in which stabilization/accumulation of EIN3/EIL1 [XV] takes place activating genes downstream of EIN2 inducing transcription cascade of ERF1 $[\mathrm{XVI}]$ and ethylene-responsive genes $[\mathrm{XVII}]^{79}$ causing the triple response, epinasty, and senescence in mango inflorescence [XVIII]. Earlier, we have shown that low-temperature stress induced cyanide/ethylene production could produce malformation symptoms ${ }^{7}[\mathrm{VI}]$ wherein Fusarium mangiferae may function through MIP $^{7}$ [XIX]. Moreover, Fusarium mangiferae has a potential to produce ethylene itself ${ }^{9}[\mathrm{XX}]$, which may add to the ethylene pool in mango inflorescences [III]. The cyanide/ethylene mediate various responses in MS include the loss of apical dominance, increased radial growth of rachis and reduced elongation of rachis and pedicel/peduncle, flower orientation (epinasty), amplified lateral florets, and crowded flowers, which become a thick mass of hyperplasic/ hypertrophied cells with deformed reproductive organs ${ }^{15,25}$ and disrupted cell organelles, necrosis and dead cells [XVIII, XXVII]. Stress-induced cyanide/ethylene production involving the generation of ROS $^{82}$ is associated with cellular organelles damage via lipid peroxidation, which requires a functional antioxidant for scavenging the ROS $^{75}$. The present study shows ASA, GSH, and GR are adversely affected [XXI] by stress-stimulated cyanide/ethylene overproduction, leading to a poor antioxidant system, causing senescence, cellular damage and cell death by unscavenged ROS [XXII]. Most plants generate cyanide as a byproduct of the ethylene biosynthesis ${ }^{64}$. Here, in MS the level of endogenous cyanide increases [XXIII] because of the higher pace of ethylene biosynthesis under stress. Moreover, the low activity of $\beta$-CAS [XXIV] leads to poor detoxification [XXV] that causes the accumulation of unmetabolized cyanide [XXVI]. Cyanide blocks the complex IV of mitochondrial ETC and inhibits ATP formation $^{31}$, leading to poor growth of MI. The hyper-toxic effect of HCN can be responsible for acute necrosis and cell death of MI [XXVII].

As described in Fig. 7B, cyanide/ethylene effects and synthesis can be inhibited by different inhibitors to protect crop from its various adverse effects on physiological and developmental processes ${ }^{83}$. These inhibitors are useful for biological research to fine-tune the mechanisms involving cyanide/ethylene synthesis and/or signal transduction ${ }^{60}$. The $\mathrm{AgNO}_{3}$ and 1-methylcyclopropane (1-MCP) have been identified to inhibit ethylene action and thereby reduced toxic cyanide effects ${ }^{84}$ whereas aminooxyacetic acid (AOA), aminoethoxyvinylglycine (AVG) and cobalt chloride (cobaltous ions) are known to inhibit cyanide and ethylene formation ${ }^{85}$. Silver ion occupies the binding site for copper at ethylene receptors, and 1-MCP blocks ethylene binding of the receptor proteins $^{86,87}$. Silver ion specifically blocks the action of ethylene in its classical physiological responses ${ }^{88}$. Here, our study shows $\mathrm{AgNO}_{3}$ reduces incidence of malformation. Cobalt ions promote growth factors alleviate the senescence of aged tissues as it inhibits the activities of ACC oxidase and reduce cyanide and ethylene production ${ }^{85,89}$. Exogenous application of cobalt chloride reduces the endogenous cyanide and ethylene concentration ${ }^{90}$. Our data showed the cobalt chloride application result in reduced incidence of necrotic malformed mango inflorescence. The proposed model will help us to comprehend the physiological and molecular basis of the mechanisms and its subsequent management underlying cyanide coproduct of ethylene as a key player in malformation.

In summary, we propose that cyanide derived from ethylene is a critical agent responsible for the MMI disease. Enzymes that regulate cyanide/ethylene production, and by-products of ethylene biosynthesis in plants, determined in this study, corroborate our hypothesis. Moreover, we have described for the first time, the impact of cyanide and ethylene on cellular morphology in HI and MI. This is the first such study providing molecular-biochemical evidence for the disease. Our data also show that cyanide production with ethylene, and its partial detoxification can be controlled by manipulating the key regulatory enzyme, ACS and $\beta$-CAS. This knowledge might be applied to manipulate mango varieties genetically for engineering resistance to malformation.

\section{Methods}

Plant materials, experimental site, and meteorological conditions. Mk, Rk and Ln cultivars showed different flowering (December to January) and fruit maturity (May to July) time ${ }^{91}$. These cultivars are diversely related each other in a study on nucleotide polymorphisms (SNPs) ${ }^{92}$. The genetic background of these cultivars described earlier showed that Rk cultivar grouped in phylogenetic cluster 5 of structure sub-population $\mathrm{I}$, while $\mathrm{Ln}$ and Mk cultivars are grouped in phylogenetic cluster 7 of structure sub-population $\mathrm{II}^{93}$. The mango cultivars Mk, Rk and Ln differing in their degree of susceptibility to mango malformation disease were selected for the present study ${ }^{75}$. Of which Mk Rk and Ln are representing highly susceptible, moderately susceptible and less susceptible cultivars ${ }^{75}$. The $\mathrm{MI}$ and $\mathrm{HI}$ were collected from twenty years old plants of $\mathrm{Mk}$, Rk and Ln cultivars of mango during winter where existing mean temperature varied 'between' $10-15^{\circ} \mathrm{C}$, and mean precipitation and relative humidity ranged between $0-0.4 \mathrm{~mm}$ and $44-66 \%$, respectively. The temperature during summer ranged from $26-46^{\circ} \mathrm{C}$. The canopy size and trunk dimension of mango cultivars were $10-12$ feet and $30-40 \mathrm{~cm}$, 
respectively. The phenological stages are divided into the growth stages for bud, leaf and shoot development, inflorescence emergence, flowering, fruit development and fruit maturity. All plants used for sampling were at the flowering stage. The experiments were carried out in the Orchard at the Department of Plant Physiology, G.B. Pant University of Agriculture and Technology, Pantnagar, which is located at $29^{\circ} \mathrm{N}$ latitude, $79.3^{\circ} \mathrm{E}$ longitude and an altitude of $243.8 \mathrm{~m}$ over mean sea level. It belongs to Gangetic Plains Region of Uttarakhand state of North India representing the Terai belt - a lowland region in the northwestern part of India, south of the outer foothills of the Himalayas, which is characterized by tall grasslands, swamps, and hot and wet summers followed by cold winter.

Alignment of ACS and $\beta$-CAS protein sequences. Protein sequence data for ACC synthase (ACS) and $\beta$-cyanoalanine synthase $(\beta$-CAS) genes from different plant species were achieved by BLAST-P searches of the National Center for Biotechnology Information (NCBI) Entrez databases ${ }^{94}$, which are listed in Supplementary Table S3. Multiple amino acid sequence alignments were made using Clustal X software to study the transcript level of ACS, and $\beta$-CAS genes in mango inflorescence ${ }^{95}$ and the primers were designed (Supplementary Table S4) from highly conserved regions for qRTPCR. However, primers for Actin were designed from the CDS sequence available in NCBI database (Accession number: At3G46520).

RNA isolation and quantitative real-time PCR (qRT-PCR). Total RNA from mango MI and HI was isolated using TRIzolH Reagent (Invitrogen, http://www.invitrogen.com) as per manufacturer's instructions, and poly(A)-RNA was isolated ${ }^{96}$. It was used to prepare cDNA using the RevertAid $\mathrm{H}$ minus first-strand cDNA synthesis kit (Fermentas, http://www.thermoscientificbio.c om/fermentas) as described previously ${ }^{97}$. The primers for all the defined genes were designed via PRIMER EXPRESS (PE Applied Biosystems, USA) with default parameters. Primers were validated using BLAST tool of NCBI. The dissociation curve was examined after the PCR reaction to check the specificity. A list of primers for qRT-PCR is shown in (Supplementary Table S4). The reaction for qRT-PCR was set up as described earlier ${ }^{98}$ in ABI 7500 Real-Time PCR System (Applied Biosystems, USA). The relative levels of the transcript accumulated for all the selected genes were normalized using $\alpha$-tubulin like the endogenous control using $2^{-\Delta \Delta \mathrm{Ct}}$ method $^{99}$. Biological and technical replicates of each given sample were studied for the analysis.

Determination of ACS activity and quantification of ethylene and cyanide. The floral tissues $(0.2 \mathrm{~g})$ were ground using mortar and pestle in $3 \mathrm{~mL}$ of extraction buffer $(0.1 \mathrm{M} \mathrm{EPPS}-\mathrm{KOH}$ buffer, $\mathrm{pH} 8.5,10 \mathrm{mM}$ 2 -mercaptoethanol, and $10 \mu \mathrm{M}$ pyridoxal phosphate) at $2^{\circ} \mathrm{C}$. ACS (EC 4.4.1.14) was extracted by the methods of Kato et al. ${ }^{100}$ with slight modification. ACC formed in the reaction was assayed by the method of Lizada and Yang ${ }^{101}$. Protein was estimated by using the method of Bradford ${ }^{102}$. Enzyme activity was expressed as the amount of ACC (nmol) produced per mg protein per hour. Ethylene content in the tissues of MI and HI of mango cultivars was quantified by following the method of Nakatsuka et al. ${ }^{103}$ using the same set of experimental conditions and gas chromatography as described by Ansari et al. ${ }^{7}$. Mango floral tissue un-metabolized cyanide (HCN) was estimated colorimetrically by the method of Lambert ${ }^{104}$ with minor modifications. The vacuum extraction was done for extracting intercellular HCN gas from $2.0 \mathrm{~g}$ of MI and HI tissues. The collection flask contained $200 \mu \mathrm{L}$ of $0.1 \mathrm{~N} \mathrm{NaOH}$ to trap the extracted $\mathrm{HCN}$ gas. To $200 \mu \mathrm{L}$ of trap solution $(0.1 \mathrm{~N} \mathrm{NaOH})$ were added $100 \mu \mathrm{L} 1 \mathrm{M}$ acetic acid, $1 \mathrm{~mL} 0.25 \%$ succinimide $/ 0.025 \% \mathrm{~N}$-chlorosuccinimide reagent, and $200 \mu \mathrm{L} 3 \%$ barbituric acid in $30 \%$ pyridine. The reaction mixtures were shaken vigorously for 10 minutes. The absorbance was read at $580 \mathrm{~nm}$, and the results were expressed in ppb.

Determination of the methionine content, total cations and anions concentration, and SAM and SAH. Floral tissues of MI and $\mathrm{HI}(0.5 \mathrm{~g})$ were weighed into a $50 \mathrm{~mL}$ conical flask containing $6 \mathrm{~mL}$ of $2 \mathrm{~N}$ $\mathrm{HCl}$ and then were autoclaved at $15 \mathrm{lb}$ pressure for $1 \mathrm{hr}$. A pinch of activated charcoal was added to the hydrolysate. It was boiled and washed with hot distilled water. The filtrate was neutralized with $10 \mathrm{~N} \mathrm{NaOH}$ to $\mathrm{pH} 6.5$. The volume was made to $50 \mathrm{~mL}$ with distilled water after cooling ambient temperature and $25 \mathrm{~mL}$ of it was transferred to $100 \mathrm{~mL}$ conical flask. Subsequently, $3 \mathrm{~mL}$ of $10 \% \mathrm{NaOH}$ and $15 \mathrm{~mL}$ of $10 \%$ sodium niterprusside (10\%) were added. After standing for 10 minutes with repeated shaking, $1 \mathrm{~mL}$ of glycine (3\%) solution was added. The mixtures were allowed to stand for another 10 minutes with frequent shaking, $2 \mathrm{~mL}$ of orthophosphoric acid was added and shook vigorously. Intensity of red color after 10 minutes was read at $520 \mathrm{~nm}$ against a blank prepared in the same way without niteroprusside. The methionine content was calculated using standard curve as described by Horn et al. ${ }^{105}$ and was expressed as $\mu \mathrm{g} \mathrm{g}^{-1} \mathrm{FW}$.

The total cations and anions concentration was determined by ion chromatography. For the analysis of cations, dry floral tissues $(0.5 \mathrm{~g})$ mango MI and HI were kept in $5 \mathrm{~mL}$ triacid mixture (nitric acid: sulphuric acid: perchloric acid, 1:1:4, v/v/v) for $20 \mathrm{~min}$. The samples were digested using a hot plate in a digestion hood. The dry digested samples were reconstituted in $5 \mathrm{~mL}$ of $6 \mathrm{~N} \mathrm{HCl}$, and the volume was made up to $20 \mathrm{~mL}$ using double distilled water. The samples were then filtered for analysis using ion chromatography using a sample size of $1 \mathrm{~mL}$, Loop size $-100 \mu \mathrm{L}$, Metrosep Cation 1-2 column, the flow rate of $1.0 \mathrm{~mL} / \mathrm{min}$. The eluent used was $4 \mathrm{mM}$ Tartaric acid plus $0.75 \mathrm{mM}$ dipicolinic acid plus $10 \%$ acetone, and the detector was set to full scale to $20 \mu \mathrm{S} / \mathrm{cm}$.

Anion analysis was carried out by homogenizing dry $0.3 \mathrm{~g}$ tissues of $\mathrm{MI}$ and $\mathrm{HI}$ in $20 \mathrm{~mL}$ deionized distilled water. The samples were filtered before analysis. The prepared samples were injected into an ion chromatograph for ion analysis. Analysis of phosphate $\left(\mathrm{PO}_{4}^{-3}\right)$ was carried out using a sample size $1 \mathrm{~mL}$ for injection, loop size $20 \mu \mathrm{L}$, column IC Sep AN2 and IC Sep ANSC, flow rate $1.2 \mathrm{~mL} / \mathrm{min}$, eluent $1 \mathrm{mM}$ Sodium carbonate $+3.5 \mathrm{mM}$ Sodium bicarbonate $+10 \%$ acetone, detector setting and full scale: $20.0 \mu \mathrm{S} / \mathrm{cm}^{106}$.

For the estimation of SAM and SAH, floral tissues (approximately $500 \mathrm{mg}$ ) of MI and HI were harvested from selected cultivars and instantly stored in liquid nitrogen at $-80^{\circ} \mathrm{C}$. The tissue was homogenized in liquid nitrogen 
and extracted at $4{ }^{\circ} \mathrm{C}$ for $20 \mathrm{~min}$ with $0.5 \mathrm{~mL}$ of $0.1 \mathrm{~N} \mathrm{HCl}$. The plant homogenate obtained was centrifuged for $10 \mathrm{~min}$ at $4^{\circ} \mathrm{C}$ and $16,400 \mathrm{~g}$ to eliminate cell debris. SAM (nmol mg protein ${ }^{-1}$ ) was estimated as described by Van de Poel et al ${ }^{107}$ with slight modification. SAH was determined as described by Bürstenbinder et al. ${ }^{24}$ after chloroacetaldehyde derivatization.

Measurement of ASA and DHA and determination of DHAR activity. Fresh floral tissues $(0.5 \mathrm{~g})$ from $\mathrm{MI}$ and $\mathrm{HI}$ each were crushed and blended in $2 \mathrm{~mL}$ of extraction buffer (100 mM, pH 7.0 with $1 \mathrm{mM}$ EDTA) and then centrifuged at $10,000 \mathrm{~g}$ for $10 \mathrm{~min}$. The supernatant was collected, and ASA and DHA were extracted and determined as described by Wang et al. ${ }^{108}$ (1991) with slight modification. A standard curve in the range of $10-100 \mathrm{nmol}$ of ascorbate was used for calibration. The DHAR activity in the sample was assayed at $265 \mathrm{~nm}$ by adopting the method of Nakano and Asada ${ }^{109}$. Protein was estimated ${ }^{102}$ using bovine serum albumin as standard.

GSH content and GR activity measurements. We homogenized $500 \mathrm{mg}$ tissue each from MI and HI in $2 \mathrm{~mL} 5 \%(\mathrm{w}: \mathrm{v})$ sulphosalicylic acid at $4{ }^{\circ} \mathrm{C}$. The homogenate was then centrifuged at $10,000 \mathrm{~g}$ for $10 \mathrm{~min}$. After centrifugation, the supernatant $(0.5 \mathrm{~mL})$ was added to $0.6 \mathrm{~mL}$ of $100 \mathrm{mM}$ (pH 7.0) phosphate buffer, $40 \mu \mathrm{L}$ of $10 \mathrm{mM} 5$,5-dithio-bis(2-nitrobenzoic acid) (DTNB), $150 \mu \mathrm{L}$ of $0.5 \mathrm{mM}$ nicotinamide adenine dinucleotide phosphate (NADPH) and GR (10 units/mL). After 2 minutes at $412 \mathrm{~nm}$ wavelength in a UV-vis spectrophotometer, the absorbance was measured to determine total glutathione. GSSG was estimated in presence of 2-vinylpyridine and GSH content was calculated by subtracting GSSG from total glutathione, and was expressed as $\mu \mathrm{mol} \mathrm{g}^{-1} \mathrm{FW}^{110}$.

Fresh MI and HI tissues $(250 \mathrm{mg})$ were homogenized in $2 \mathrm{~mL}$ of extraction buffer containing $100 \mathrm{mM}$ potassium-phosphate buffer ( $\mathrm{pH}$ 7.0), 1.0 mM EDTA, 2.0 mM dithiothreitol (DTT), $1.0 \mathrm{mM}$ phenylmethanesulfonyl fluoride (PMSF), $0.05 \%(\mathrm{v} / \mathrm{v})$ Triton X-100, $10 \%(\mathrm{v} / \mathrm{v})$ glycerol and $1 \%(\mathrm{w} / \mathrm{v})$ polyvinylpyrrolidone (PVP) at $4{ }^{\circ} \mathrm{C}$. The extract was then centrifuged at $12,000 \mathrm{~g}$ for $20 \mathrm{~min}$ at $4{ }^{\circ} \mathrm{C}$. The GR (EC 1.6.4.2) activity was estimated by adding $0.1 \mathrm{~mL}$ of crude enzyme extract to $0.9 \mathrm{~mL}$ of a reaction medium consisting of $100 \mathrm{mM}$ potassium phosphate buffer ( $\mathrm{pH} 7.5$ ), 1.0 mM ethylenediaminetetraacetic acid (EDTA), 1.0 mM GSSG, and 0.1 mM NADPH $0.5 \mathrm{mM}$ Tris- $\mathrm{HCl}$. GR activity $\left(\mathrm{U} \mathrm{mg}^{-1}\right.$ protein $\mathrm{min}^{-1}$ ) was measured as described by Foyer and Halliwell ${ }^{111}$ by monitoring the rate of decline in the absorbance of NADPH at $340 \mathrm{~nm}$ (extinction coefficient $6.22 \mathrm{mM}^{-1} \mathrm{~cm}^{-1}$ ).

$\beta$-cyano alanine synthase assay and determination of tissue un-metabolized cyanide. One gram tissue from each MI and HI was ground in $0.2 \mathrm{M}$ Tris-Buffer ( $\mathrm{pH}$ 8.5). The homogenate was centrifuged at $10,000 \mathrm{~g}$ for $20 \mathrm{~min}$ and the supernatant was collected. The method of Miller and Conn ${ }^{32}$ was followed for $\beta$-cyano alanine synthase (EC 4.4.1.9) assay with slight modification. The reaction was performed in a serum capped vials containing $0.2 \mathrm{~mL}$ of supernatant containing enzyme extract, $0.8 \mathrm{~mL}$ Tris buffer $(0.1 \mathrm{M}, \mathrm{pH} 8.5), 25 \mathrm{mM} \mathrm{L}$-cysteine, and $25 \mathrm{mM} \mathrm{NaCN}$ in a final volume of $1 \mathrm{~mL}$. After incubation in water bath at $35^{\circ} \mathrm{C}$ for 30 minutes, the reaction was stopped by injecting $100 \mu \mathrm{L} 20 \mathrm{mM} N, N$-dimethyl-p-phenylenediamine in $7.2 \mathrm{~N} \mathrm{HCI}$ and $100 \mu \mathrm{L} 30 \mathrm{mM}$ ferric chloride $\left(\mathrm{FeCl}_{3}\right)$ in $1.2 \mathrm{~N} \mathrm{HC1}$ through the serum cap. The color developed due to the presence of $\mathrm{H}_{2} \mathrm{~S}$ was measured at $650 \mathrm{~nm}$, using sodium sulfide $\left(\mathrm{Na}_{2} \mathrm{~S}\right)$ as the standard. $\beta$-cyano alanine synthase activity was expressed as $\mathrm{nmol} \mathrm{H}_{2} \mathrm{~S}$ $\mathrm{mg}^{-1}$ protein $\mathrm{min}^{-1}$. Protein was estimated by the method of Lowry et al. ${ }^{112}$. Mango floral tissue un-metabolized HCN was estimated colorimetrically by the method of Lambert ${ }^{104}$ with minor modifications as shown above.

Transmission electron microscopic study of mango inflorescence. Floral tissues from MI and HI of mango cultivars were fixed in a solution containing $2.5 \%(\mathrm{w} / \mathrm{v})$ glutaraldehyde and $2.5 \%(\mathrm{w} / \mathrm{v})$ formaldehyde in $0.1 \mathrm{M} \mathrm{NaPO}_{4}$ buffer $(\mathrm{pH} 7.3 \pm 0.05)$. Ultrathin microtome sections $(50-60 \mathrm{~nm})$ were examined using a Jeol 1010 electron microscope (Tokyo, Japan) equipped with a CCD Megaview camera, operated at $100 \mathrm{kV}$ by as described by Shibuya et al..$^{13}$. Before TEM observation, these sections were treated with $2 \%$ aqueous uranyl acetate for $20 \mathrm{~min}$ and lead citrate for $5 \mathrm{~min}^{114}$.

Field trial study to evaluate the response of ethrel and ethylene inhibitors on incidence mango malformation. The MI and $\mathrm{HI}$ of twenty years old plants of six mango cultivars Mk, Rk and Ln were selected for conducting a field trial study of ethrel and ethylene inhibitors at G.B. Pant University of Agriculture and Technology, Pantnagar, Uttarakhand, India. The study was conducted during the flowering season in two consecutive years. Ethrel $(0,50,100$ and $200 \mathrm{ppm})$ treatment was given in the last week of December during the flowering season of years 2009 and 2010. Ethylene inhibitors, such as silver nitrate $\left(\mathrm{AgNO}_{3}\right)(50-800 \mathrm{ppm})$ and cobalt chloride $\left(\mathrm{CoCl}_{2}\right)(50-1000 \mathrm{ppm})$, were sprayed in the last week of December during the flowering season of 2013. Observations were taken in March by randomly selecting approximately a hundred inflorescences. The percentage of MI was recorded from a total of 300 panicles per plant.

Statistical analysis. One-Way ANOVA unifactorial analysis was performed on each variable. Means were separated by using Tukey's Post hoc HSD test to compare significant differences between treatments $P<0.05$. All statistical analyses were performed with performed with XLSTAT, version 2013.3.05 (Addinsoft Inc).

Received: 18 June 2019; Accepted: 14 November 2019;

Published online: 04 December 2019

\section{References}

1. Randhawa, G. S. \& Damodaran, V. K. Studies on floral biology and sex-ratio in mango (Mangifera indica L.: A review. Indian Journal of Horticulture 18, 9-35 (1961).

2. Ramírez, F. \& Davenport, T. L. Mango (Mangifera indica L.) pollination: a review. Scientia Horticulturae 203, 158-168 (2016).

3. Ploetz, R. C. Malformation: a unique and important disease of mango (Mangifera indica L.). In Fusarium: Paul E Nelson memorial symposium St Paul (Summerell, B. A., Leslie, J. F., Backhouse, D., Bryden, W. L. \& Burgess, L. W., eds). APS Press, Minnesota, pp. 233-247 (2001). 
4. Kumar, P., Misra, A. K. \& Modi, D. R. Current status of mango malformation in India. Asian Journal of Plant Sciences 10, 1-23 (2011).

5. Watt, G. A dictionary of economic products of India. vol. 5, Govt. Printing Press, Calcutta, pp: 149 (1891).

6. Campbell, C. W. \& Marlatt, R. Current status of mango malformation disease in Florida. Proceedings of the Interamerican Society for Tropical Horticulture 30, 223-226 (1986).

7. Ansari, M. W., Bains, G., Shukla, A., Pant, R. C. \& Tuteja, N. Low temperature stress ethylene and not Fusarium, might be responsible for mango malformation. Plant Physiology and Biochemistry 69, 34-38 (2013a).

8. Singh, A. et al. First evidence of putrescine involvement in mitigating the floral malformation in mangoes: A scanning electron microscope study. Protoplasma 251, 1255-1261 (2014).

9. Ansari, M. W., Shukla, A., Pant, R. C. \& Tuteja, N. First evidence of ethylene production by F. mangiferae associated with mango malformation. Plant Signaling and Behavior 8, e22673 (2013b).

10. Joshi, B. et al. Fusarium mangiferae associated with mango malformation in the tarai region of the Uttarakhand state of India. Plant Signaling and Behavior 9, e28715 (2014).

11. Wu, J. et al. Development of a sensitive molecular detection assay for mango malformation disease caused by Fusarium mangiferae. Biotechnology Letters 38, 835-840 (2016).

12. Vrabka, J. et al. Production and role of hormones during interaction of Fusarium species with maize (Zea mays L.) seedlings. Frontiers in Plant Science 9, 1936 (2019).

13. Arenas-Alfonseca, L., Gotor, C., Romero, L. C. \& García, I. Role of mitochondrial cyanide detoxification in Arabidopsis root hair development. Plant Signaling and Behavior 31, 1-3 (2018).

14. Yu, L., Liu, Y. \& Xu, F. Comparative transcriptome analysis reveals significant differences in the regulation of gene expression between hydrogen cyanide- and ethylene-treated Arabidopsis thaliana. BMC Plant Biology 19, 92 (2019).

15. Rani, V., Ansari, M. W., Shukla, A., Tuteja, N. \& Bains, G. Fused lobed anther and hooked stigma affect pollination, fertilization and fruit set in mango. Plant Signaling and Behavior 8, e23167 (2013).

16. Del-Cueto, J. et al. (2018) Cyanogenic Glucosides and Derivatives in Almond and Sweet Cherry Flower Buds from Dormancy to Flowering. Frontiers in Plant Science 8, 800 (2017).

17. Yang, S. F. \& Hoffman, N. E. Ethylene biosynthesis and its regulation in higher plants. Annu. Rev. Plant Physiology 35, 155-189 (1984).

18. Vaseva, I. I. et al. The plant hormone ethylene restricts Arabidopsis growth via the epidermis. Proceedings of the National Academy of Sciences of USA 115, E4130-E4139 (2018).

19. Han, X., Li, G. \& Zhang, S. Assay methods for ACS activity and ACS phosphorylation by MAP kinases in vitro and in vivo. Methods in Molecular Biology 1573, 59-71 (2017).

20. Sato, T. \& Theologis, A. Cloning the mRNA encoding 1-aminocyclopropane-1-carboxylate synthase, the key enzyme for ethylene biosynthesis in plants. Proceedings of the National Academy of Sciences of USA 86, 6621-6625 (1989).

21. Wen, C. M., Wu, M., Gho, C. J. \& Pua, E. C. Plant gene register nucleotide sequence of a cDNA clone encoding 1-aminocyclopropane-1-carboxylate synthase in mustard (Brassica juncea [L.] Czern and Coss). Plant Physiology 103, 1019-1020 (1993).

22. Manzano, S. et al. The ethylene biosynthesis gene CitACS4 regulates monoecy/andromonoecy in watermelon (Citrullus lanatus). PLoS One. 11, e0154362 (2016).

23. Wang, S. Y., Adams, D. O. \& Lieberman, M. Recycling of 5'-methylthioadenosine-ribose carbon atoms into methionine in tomato tissue in relation to ethylene production. Plant Physiology 70, 117-121 (1982).

24. Bürstenbinder, K., Rzewuski, G., Wirtz, M., Hell, R. \& Sauter, M. The role of methionine recycling for ethylene synthesis in Arabidopsis. The Plant Journal 49, 238-249 (2007).

25. Ansari, M. W. et al. Mango (Mangifera indica L.) malformation: a malady of stress ethylene origin. Physiology and Molecular Biology of Plants 21, 1-8 (2015).

26. Lin, Z., Zhong, S. \& Grierson, D. Recent advances in ethylene research. Journal of Experimental Botany 60, 3311-3336 (2009).

27. Shimaoka, T., Miyake, C. \& Yokota, A. Mechanism of the reaction catalyzed by dehydroascorbate reductase from spinach chloroplasts. European Journal of Biochemistry 270, 921-928 (2003).

28. Chin, D. C., Hsieh, C. C., Lin, H. Y. \& Yeh, K. W. A low glutathione redox state couples with a decreased ascorbate redox ratio to accelerate flowering in Oncidium orchid. Plant Cell and Physiology 57, 423-436 (2016).

29. Bains, G. \& Pant, R. C. Mango malformation: etiology and preventive measures. Physiology and Molecular Biology of Plants $\mathbf{9}$, 41-61 (2003).

30. Siegieñ, I. \& Bogatek, R. Cyanide action in plants: from toxic to regulatory. Acta Physiologiae Plantarum 28, $483-497$ (2006).

31. Seo, S. et al. Cyanide, a coproduct of plant hormone ethylene biosynthesis, contributes to the resistance of rice to blast fungus. Plant Physiology 155, 502-514 (2011).

32. Miller, J. M. \& Conn, E. E. Metabolism of hydrogen cyanide by higher plants. Plant Physiology 65, 1199-1202 (1980).

33. Hatzfeld, Y. et al. Beta-Cyanoalanine synthase is a mitochondrial cysteine synthase-like protein in spinach and Arabidopsis. Plant Physiology 123, 1163-1171 (2000).

34. Bleecker, A. B. \& Kende, H. Ethylene: A gaseous signal molecule in plants. Annual Review of Cell and Developmental Biology 16, $1-18(2000)$

35. Novero, A. U. Current status of research on o-acetylserine (thiol) lyase and $\beta$-cyanoalanine synthase, two enzymes of plant cysteine biosynthesis- a review. Plant Omics Journal 2, 181-189 (2009).

36. Freeman, S., Levin, A. G., Maymon, M., Shtienberg, D. \& Ploetz, R. C. Mango malformation - new insights into disease epidemiology provide an opportunity to develop novel management strategies. Plant Disease 98, 1456-1466 (2014).

37. Iqbal, Z. et al. Management of mango malformation through physical alteration and chemical spray. African Journal of Agricultural Research 6, 1897-1901 (2011).

38. Liu, F., Wu, J. B., Zhan, R. L. \& Ou, X. C. Transcription profiling analysis of mango-Fusarium mangiferae interaction. Frontiers in Microbiology 7, 1443 (2016).

39. Bailey, B. A. Purification of a protein from culture filtrates of Fusarium oxysporum that induces ethylene and necrosis in leaves of Erythroxylum coca. Phytopathology 85, 1250-1255 (1995).

40. Wang, N. N. The GUS reporter-aided analysis of the promoter activities of Arabidopsis ACC synthase genes AtACS4, AtACS5, and AtACS7 induced by hormones and stresses. Journal of Experimental Botany 56, 909-920 (2005).

41. Zhu, J. H., Xu, J., Chang, W. J. \& Zhang, Z. L. Isolation and molecular characterization of 1-aminocyclopropane-1-carboxylic acid synthase genes in Hevea brasiliensis. International Journal of Molecular Sciences 16, 4136-4149 (2015).

42. Harada, T. et al. Analysis of genomic DNA of DcACS1, a 1-aminocyclopropane-1-carboxylate synthase gene, expressed in senescing petals of carnation (Dianthus caryophyllus) and its orthologous genes in D. superbus var. longicalycinus. Plant Cell Reports 30, 519-527 (2011).

43. Bai, S. et al. Transcriptome analysis of japanese pear (Pyrus pyrifolia Nakai) flower buds transitioning through endodormancy. Plant and Cell Physiology 54, 1132-1151 (2013).

44. Ichimura, K. \& Niki, T. Ethylene production associated with petal senescence in carnation flowers is induced irrespective of the gynoecium. Journal of Plant Physiology 171, 1679-1684 (2014). 
45. Pan, H. C., Li, J. H. \& Wang, X. Z. Involvement of ethylene and 1-aminocyclopropane-1-carboxylate synthase gene in regulation of programmed cell death during rose (Rosa x hybrida) flower development. Zhi Wu Sheng Li Yu Fen Zi Sheng Wu Xue Xue Bao 31, 354-360 (2005).

46. Bradford, K. J. Shang Fa Yang: Pioneer in plant ethylene biochemistry. Plant Science 175, $2-7$ (2008).

47. Vanderstraeten, L. \& Van-Der-Straeten, D. Accumulation and transport of 1-aminocyclopropane-1-carboxylic acid (ACC) in plants: current status, considerations for future research and agronomic applications. Frontiers in Plant Science 8, 38 (2017).

48. Shukla, D., Rinehart, C. A. \& Sahi, S. V. Comprehensive study of excess phosphate response reveals ethylene mediated signaling that negatively regulates plant growth and development. Scientific Reports 7, 3074 (2017).

49. Zagorchev, L., Seal, C. E., Kranner, I. \& Odjakova, M. A central role for thiols in plant tolerance to abiotic stress. International Journal of Molecular Sciences 14, 7405-7432 (2013).

50. Moffatt, B. A. \& Weretilnyk, E. A. Sustaining S-adenosyl-1-methionine-dependent methyltransferase activity in plant cells. Physiologia Plantarum 113, 435-442 (2001).

51. Hameed, A. et al. Effects of salinity and ascorbic acid on growth, water status and antioxidant system in a perennial halophyte. AoB Plants 7, https://doi.org/10.1093/aobpla/plv004 (2015).

52. Venkatesh, J. \& Park, S. W. Role of L-ascorbate in alleviating abiotic stresses in crop plants. Botanical Studies 55, 38 (2014).

53. Mirica, L. M. \& Klinman, J. P. The nature of $\mathrm{O}_{2}$ activation by the ethylene-forming enzyme 1-aminocyclopropane-1-carboxylic acid oxidase. Proceedings of the National Academy of Sciences of the United States of America 105, 1814-1819 (2008).

54. Lee, Y. et al. The effect of ascorbic acid and dehydroascorbic acid on the root gravitropic response in Arabidopsis thaliana. Plant Physiology and Biochemistry 49, 909-916 (2011).

55. Cao, Y. et al. Lack of salicylic acid in Arabidopsis protects plants against moderate salt stress. Zeitschrift für Naturforschung C 64, 231-238 (2009)

56. Pandey, P., Singh, J., Achary, V. \& Reddy, M. K. Redox homeostasis via gene families of ascorbate-glutathione pathway. Frontiers in Environmental Science 3, 25 (2015).

57. Noctor, G. \& Foyer, C. H. Ascorbate and glutathione: the heart of the redox hub. Plant Physiology 155, 2-18 (2011).

58. Mazorra-Morales, L. M. et al. Impact of brassinosteroids and ethylene on ascorbic acid accumulation in tomato leaves. Plant Physiology and Biochemistry 74, 315-322 (2014).

59. Gergoff, G., Chaves, A. \& Bartoli, C. G. Ethylene regulates ascorbic acid content during dark-induced leaf senescence. Plant Science 178, 207-212 (2010).

60. Iqbal, N. et al. Ethylene role in plant growth, development and senescence: interaction with other phytohormones. Frontiers in Plant Science 8, 475 (2017).

61. Peiser, G. D., Wang, T. T., Hoffman, N. E., Yang, S. F. \& Walsh, C. T. Formation of cyanide from carbon-1 of 1-amino-cyclopropane1-carboxylic acid during conversion to ethylene. Proceedings of the National Academy of Sciences of the United States of America 81, 3059-3063 (1984).

62. Yip, W. K. \& Yang, S. F. Cyanide metabolism in relation to ethylene production in plant tissues. Plant Physiology 88, 473-476 (1988).

63. Lai, K. W., Yau, C. P., Tse, Y. C., Jiang, L. \& Yip, W. K. Heterologous expression analyses of rice OsCAS in Arabidopsis and in yeast provide evidence for its roles in cyanide detoxification rather than in cysteine synthesis in vivo. Journal of Experimental Botany 60, 993-1008 (2009).

64. Zidenga, T., Siritunga, D. \& Sayre, R. T. Cyanogen metabolism in Cassava roots: impact on protein synthesis and root development. Frontiers in Plant Science 8, 220 (2017).

65. Wurtele, E. S., Nikolau, B. J. \& Conn, E. E. Tissue distribution of beta-cyanoalanine synthase in leaves. Plant Physiology 75, 979-982 (1984).

66. Manning, K. Ethylene production and $\beta$-cyanoalanine synthase activity in carnation flowers. Planta 168, 61-66 (1986).

67. Machingura, M., Salomon, E., Jez, J. M. \& Ebbs, S. D. The $\beta$-cyanoalanine synthase pathway: beyond cyanide detoxification. Plant, Cell \& Environment 39, 2329-2341 (2016).

68. Yi, H., Juergens, M. \& Jez, J. M. Structure of soybean $\beta$-cyanoalanine synthase and the molecular basis for cyanide detoxification in plants. Plant Cell 24, 2696-2706 (2012).

69. García, I., Gotor, C. \& Romero, L. C. Beyond toxicity: a regulatory role for mitochondrial cyanide. Plant Signaling \& Behavior 9 , e27612 (2014)

70. Kazan, K. Diverse roles of jasmonates and ethylene in abiotic stress tolerance. Trends in Plant Science 20, 219-229 (2015).

71. Li, A., Wang, Y. \& Wu, H. Initiation and development of resin ducts in the major organs of Pinus massoniana. Frontiers of Forestry in China 4, 501-507 (2009).

72. Lieberman, S. J., Valdovinos, J. G. \& Jensen, T. E. A morphometric study on the effects of ethylene treatment in promoting abscission of tobacco flower pedicels. Plant Physiology 72, 583-585 (1983).

73. Makwana, V. \& Robin, P. Interaction between GA and ethrel in inducing female flowers in Jatropha curcas. International Journal of Biotechnology and Bioengineering Research 4, 465-472 (2013)

74. Bae, H. Necrosis- and ethylene-inducing peptide from Fusarium oxysporum induces a complex cascade of transcripts associated with signal transduction and cell death in Arabidopsis. Plant Physiology 141, 1056-1067 (2006)

75. Singh, O. P. et al. Enzymatic reactive oxygen species (ROS) scavenging system in mango varieties resistant and susceptible to malformation. Scientia Horticulturae 138, 81-89 (2012).

76. Jouyban, Z. Ethylene biosynthesis. Technical Journal of Engineering and Applied Sciences 1, 107-110 (2012).

77. De Martinis, D., Koyama, T. \& Chang, C. Ethylene is all around. Frontiers in Plant Science 6, 76 (2015).

78. Tsuchisaka, A. et al. A combinatorial interplay among the 1-aminocyclopropane-1-carboxylate isoforms regulates ethylene biosynthesis in Arabidopsis thaliana. Genetics 183, 979-1003 (2009)

79. Yang, C., Lu, X., Ma, B., Chen, S. Y. \& Zhang, J. S. Ethylene signaling in rice and Arabidopsis: conserved and diverged aspects. Molecular Plant 8, 495-505 (2015).

80. Guo, H. \& Ecker, J. R. The ethylene signaling pathway: new insights. Current Opinion in Plant Biology 7, 40-49 (2004).

81. Wen, X. et al. Activation of ethylene signaling is mediated by nuclear translocation of the cleaved EIN2 carboxyl terminus. Cell Research 22, 1613-1616 (2012).

82. Gill, S. S. \& Tuteja, N. Reactive oxygen species and antioxidant machinery in abiotic stress tolerance in crop plants. Plant Physiology and Biochemistry 48, 909-930 (2010).

83. Schaller, G. E. \& Binder, B. M. Inhibitors of ethylene biosynthesis and signaling. Methods in Molecular Biology 1573, 223-235 (2017).

84. Beyer, E. M. A potent inhibitor of ethylene action in plants. Plant Physiology 58, 268-271 (1976a).

85. Lau, O. L. \& Yang, S. F. Inhibition of ethylene production by cobaltous ion. Plant Physiology 58, 114-117 (1976).

86. Beyer, E. M. Silver ion: a potent anti-ethylene agent in cucumber and tomato. Horticultural Science 11, 175-196 (1976b).

87. Binder, B. M., Rodriguez, F. I., Bleecker, A. B. \& Patterson, S. E. The effects of group 11 transition metals, including gold, on ethylene binding to the ETR1 receptor and growth of Arabidopsis thaliana. FEBS Letters 581, 5105-5109 (2007).

88. Strader, L. C., Beisner, E. R. \& Bartel, B. Silver ions increase auxin efflux independently of effects on ethylene response. Plant Cell 21, 3585-3590 (2009) 
89. Sarropoulou, V., Dimassi-Theriou, K. \& Therios, I. Effect of the ethylene inhibitors silver nitrate, silver sulfate, and cobalt chloride on micropropagation and biochemical parameters in the cherry rootstocks CAB-6P and Gisela 6. Turkish Journal of Biology 40, 670-683 (2016).

90. Alarcón, M. V. et al. Effects of antagonists and inhibitors of ethylene biosynthesis on maize root elongation. Plant Signaling \& Behavior 4, 1154-1156 (2016).

91. Kishore, K., Singh, H. S., Kurian, R. M., Srinivas, P. \& Samant, D. Performance of certain mango varieties and hybrids in east coast of India. Indian Journal of Plant Genetic Resources 28, 296-302 (2015).

92. Iquebal, M. A. et al. MiSNPDb: a web-based genomic resources of tropical ecology fruit mango (Mangifera indica L.) for phylogeography and varietal differentiation. Scientific Reports 7, 14968, https://doi.org/10.1038/s41598-017-14998-2 (2017).

93. Singh, N. K. et al. Origin, Diversity and Genome Sequence of Mango (Mangifera indica L.). Indian Journal of History of Science 51.2.2,355-368 (2016).

94. Altschul, S. Gapped BLAST and PSI-BLAST: a new generation of protein database search programs. Nucleic Acids Research 25, 3389-3402 (1997).

95. Thompson, J. The CLUSTAL_X windows interface: flexible strategies for multiple sequence alignment aided by quality analysis tools. Nucleic Acids Research 25, 4876-4882 (1997).

96. Xiao, J. N., Huang, X. L., Li, Y. L., Huang, X. L. \& Li, X. J. RNA extraction from cotyledon of mango with high levels of secondary substances and carbohydrates. China Biotechnology 23, 53-56 (2003).

97. Tuteja, N., Sahoo, R. K., Garg, B. \& Tuteja, R. OsSUV3 dual helicase functions in salinity stress tolerance by maintaining photosynthesis and antioxidant machinery in rice (Oryza sativa L. cv. IR64). The Plant Journal 76, 115-127 (2013).

98. Kamrul-Huda, K. M., Yadav, S., Akhter-Banu, M. S., Trivedi, D. K. \& Tuteja, N. Genome-wide analysis of plant-type II Ca ${ }^{2+}$ ATPases gene family from rice and Arabidopsis: Potential role in abiotic stresses. Plant Physiology and Biochemistry 65, 32-47 (2013).

99. Livak, K. J. \& Schmittgen, T. D. Analysis of relative gene expression data using real-time quantitative PCR and the $2^{-\Delta \Delta C T}$ method. Methods 25, 402-408 (2001).

100. Kato, M., Hayakawa, Y., Hyodo, H., Ikom, Y. \& Yano, M. Wound-induced ethylene synthesis and expression and formation of 1-aminocyclopropane-1-carboxylate (ACC) synthase, ACC oxidase, phenylalanine ammonia-lyase, and peroxidase in wounded mesocarp tissue of Cucurbita maxima. Plant Cell Physiol. 41, 440-447 (2000).

101. Lizada, M. C. \& Yang, S. F. A simple and sensitive assay for 1-aminocyclopropane-1-carboxylic acid. Analytical Biochemistry 100, 140-145 (1979).

102. Bradford, M. M. A rapid and sensitive method for the quantitation of microgram quantities of protein utilizing the principle of protein-dye binding. Analytical Biochemistry 72, 248-254 (1976).

103. Nakatsuka, A., Shiomi, S., Kubo, Y. \& Inaba, A. Expression and internal feedback regulation of ACC synthase and ACC oxidase genes in ripening tomato fruit. Plant and Cell Physiology 38, 1103-1110 (1997).

104. Lambert, J. L., Ramasamy, J. \& Paukstelis, J. V. Stable reagents for the colorimetric determination of cyanide by modified Koenig reactions. Analytical Chemistry 47, 916-918 (1975).

105. Horn, M. J., Jone, D. B. \& Blum, A. E. Colorimetric determination of methonine in proteins and foods. Journal of Biological Chemistry 116, 313-320 (1946).

106. Shahzad, M., Witzel, K., Zörb, C. \& Mühling, K. H. Growth-related changes in subcellular ion patterns in maize leaves (Zea mays L.) under salt stress. Journal of Agronomy and Crop Science 198, 46-56 (2012).

107. Van de Poel, B. et al. Determination of S-adenosyl-1-methionine in fruits by capillary electrophoresis. Phytochemical Analysis 21, 602-608 (2010).

108. Wang, S. Y., Jiao, H. J. \& Faust, M. Changes in ascorbate, glutathione, and related enzyme activities during thidiazuron-induced bud break of apple. Physiologia Plantarum 82, 231-236 (1991).

109. Nakano, Y. \& Asada, K. Hydrogen peroxide scavenged by ascorbate specific peroxidase in spinach chloroplast. Plant and Cell Physiology 22, 867-880 (1981).

110. Law, M. Y., Charles, S. A. \& Halliwell, B. Glutathione and ascorbic acid in spinach (Spinacia oleracea) chloroplasts. Biochemical Journal 210, 899-903 (1983).

111. Foyer, C. H. \& Halliwell, B. The presence of glutathione and glutathione reductase in chloroplasts: a proposed role in ascorbic acid metabolism. Planta 133, 21-25 (1976).

112. Lowry, O. H., Rosenbrough, N. H., Farr, A. L. \& Randall, R. J. Proetin measurement with the Folin phenol reagent. Journal of Biological Chemistry 193, 265-275 (1951).

113. Shibuya, K., Niki, T. \& Ichimura, K. Pollination induces autophagy in petunia petals via ethylene. Journal of Experimental Botany 64, 1111-1120 (2013).

114. Reynolds, E. S. The use of lead citrate at high pH as an electron-opaque stain in electron microscopy. Journal of Cell Biology 17, 208-212 (1963).

\section{Acknowledgements}

M.W.A. is thankful to Science and Engineering Research Board, statutory body under the Department of Science and Technology, Government of India for funding. Work on signal transduction and plant stress tolerance studies in NT's laboratory were partially supported by Department of Biotechnology, Government of India. We thank Dr. N.K. Sand, Department of Chemistry, G.B. Pant University of Agriculture and Technology, Pantnagar for providing facility to perform gas liquid chromatography.

\section{Author contributions}

M.W.A., S.K., G.B., S.T., B.J. and V.R. performed the experiments. M.W.A., S.K. and G.B. analyzed the data, and M.W.A., S.K. and R.K.W. wrote the paper. R.R. and R.T. designed the research work with the lead author, critically read the manuscript, and edited it. R.C.P., A.S. and N.T. conceived and designed the study and helped in writing. All authors read and approved the manuscript.

\section{Competing interests}

The authors declare no competing interests.

\section{Additional information}

Supplementary information is available for this paper at https://doi.org/10.1038/s41598-019-54787-7.

Correspondence and requests for materials should be addressed to N.T.

Reprints and permissions information is available at www.nature.com/reprints. 
Publisher's note Springer Nature remains neutral with regard to jurisdictional claims in published maps and institutional affiliations.

(c) (i) Open Access This article is licensed under a Creative Commons Attribution 4.0 International License, which permits use, sharing, adaptation, distribution and reproduction in any medium or format, as long as you give appropriate credit to the original author(s) and the source, provide a link to the Creative Commons license, and indicate if changes were made. The images or other third party material in this article are included in the article's Creative Commons license, unless indicated otherwise in a credit line to the material. If material is not included in the article's Creative Commons license and your intended use is not permitted by statutory regulation or exceeds the permitted use, you will need to obtain permission directly from the copyright holder. To view a copy of this license, visit http://creativecommons.org/licenses/by/4.0/.

(c) The Author(s) 2019 